\title{
Sources and physicochemical characteristics of submicron aerosols during three intensive campaigns in Granada (Spain)
}

del Águila A..$^{\text {a, }}$, Sorribas M. ${ }^{\mathrm{a}}$, Lyamani H. ${ }^{\mathrm{b}, \mathrm{c}}$, Titos G. ${ }^{\text {b,d }}$, Olmo F.J. ${ }^{\mathrm{b}, \mathrm{c}}$, Arruda-Moreira G. ${ }^{\mathrm{b}, \mathrm{e}}$, Yela M. ${ }^{\mathrm{a}}$ and Alados-Arboledas L. ${ }^{\mathrm{b}, \mathrm{c}}$

a National Institute for Aerospace Technology (INTA), Atmospheric Research and Instrumentation Branch, Mazagón, Huelva 21130, Spain

${ }^{\mathrm{b}}$ Andalusian Institute for Earth System Research, IISTA-CEAMA, University of Granada, Junta de Andalucía, Granada 18006, Spain

${ }^{c}$ Department of Applied Physics, University of Granada, Granada 18071, Spain

d Institute of Environmental Assessment and Water Research (IDÆA), Department of Geosciences, CSIC, Barcelona, Spain

${ }^{\mathrm{e}}$ Institute of Energetic and Nuclear Research (IPEN), Sâo Paulo, Brazil

* Corresponding author: Ana del Águila Pérez

E-mail: anadelaguilap@gmail.com

National Institute for Aerospace Technology (INTA), Atmospheric Research and Instrumentation Branch, Mazagón, Huelva, 21130, Spain https://doi.org/10.1016/j.atmosres.2018.06.004 


\begin{abstract}
Aerosol particles in the submicron range and their physicochemical characteristics were investigated for the first time in Granada, southeastern Iberian Peninsula, during three intensive campaigns. The physical and chemical characteristics were analysed during two spring campaigns and one autumn campaign. New particle formation (NPF) events were found to be more frequent in spring than in autumn. The mean duration, growth rates and maximum diameters had ranges of 5.3-13.2 hours, 2.4-4.0 $\mathrm{nm} \mathrm{h}^{-1}$ and 35-47 $\mathrm{nm}$, respectively. In addition, one shrinkage event occurred and had a duration of 2.2 hours and a shrinkage rate of $-2.5 \mathrm{~nm} \mathrm{~h}^{-1}$. During a period of atmospheric stagnation conditions under the influence of mountain breezes, three consecutive NPF events occurred. The high frequency of the NPF events was attributed to higher temperature and radiation levels and lower relative humidity than during a previous day with similar stagnant conditions but no nucleation occurrence. According to correlation analysis, mineral components correlated with particle number in the Aitken mode, while metals and secondary inorganic aerosols correlated with particle number in the finer and larger fractions, respectively. Pollutants such as $\mathrm{CO}, \mathrm{NO}_{2}, \mathrm{NO}$ and black carbon showed moderate and high correlations with particle number in the submicron fraction. To assess the impact of the particle number contribution according to sources, a new approach was introduced using black carbon concentrations, resulting in four major contributors: urban background, traffic, NPF and biomass burning. The proposed approach was validated by means of different models based on the aerosol spectral dependencies and chemical compositions that classify aerosol populations. Both the models and the proposed approach identified biomass burning and fossil fuel particles during the same periods, and the results showed good agreement. The proposed approach can guide future studies attempting to account for submicron particle contributions in other urban environments.
\end{abstract}

Keywords: Submicron size distribution, Chemical composition, Source apportionment, New particle formation, Biomass burning, Traffic contribution. 


\section{Introduction}

The study of the effects of atmospheric aerosols on climate has attracted the attention of the scientific community, mainly as a result of the evidence revealed by the Intergovernmental Panel on Climate Change (IPCC, 2013). Atmospheric aerosols can affect the Earth's radiative balance and global climate system directly by absorbing and scattering solar radiation or indirectly by changing the microphysical properties of clouds (e.g., Altaratz et al., 2014; Esteve et al., 2014). Thus, it is essential to measure the atmospheric aerosol properties for a better understanding of their effects on climate.

Additionally, atmospheric aerosols have a considerable impact on human health (Lightly et al., 2011), particularly particles in the finest size range (Oberdörster et al., 2005). Thus, these impacts have attracted scientific and policy-maker interest. For example, European legislation regulates the limit values of particulate matter with diameters below 10 and 2.5 microns $\left(\mathrm{PM}_{10}\right.$ and $\mathrm{PM}_{2.5}$ respectively) and gas pollutants by means of the European Directive 2008/50/EC (http://ec.europa.eu/environment/air/quality/legislation/existing_leg.htm). However, no regulations exist concerning the number concentration of ultrafine particles (UFPs, particles with diameters below $0.1 \mu \mathrm{m}$ ), although several studies have reported that UFP exposure is associated with morbidity and mortality (Pope et al., 2009), as well as respiratory and cardiovascular diseases (Pope and Dockery, 2006). Relative to $\mathrm{PM}_{10}$, UFPs can produce similar or greater increases in health risks because of their small size, large surface area and elevated number concentrations. UFPs dominate not only the particle number concentration but also the surface area, so they are likely to carry large concentrations of air pollutants, such as black carbon (BC), and reach cardiovascular target sites (Delfino et al., 2005).

Granada is a non-industrialized medium-sized city surrounded by mountains. Levels of $\mathrm{PM}_{10}$ and $\mathrm{NO}_{2}$ eventually exceed the threshold limits governed by the European legislation. Furthermore, the levels are similar or even higher than those observed in large Spanish cities, such as Barcelona and Madrid. In Granada, levels of pollution are accentuated in the cold season (Patrón et al., 2017) due to the contribution of domestic heating (Lyamani et al., 2008) and emissions from the burning of agricultural waste in rural areas near the city (Titos et al., 2017). This situation has led authorities to establish measures to reduce pollution levels (Titos et al., 2015).

A long-term monitoring program has been carried out in the urban area of Granada during recent decades to thoroughly study the atmospheric aerosol properties. The synergistic use of atmospheric aerosol measurements obtained in Granada from multiple platforms, sensors and instruments has allowed the characterization of the aerosols at surface level (Lyamani et al., 2008, 2010; Segura et al., 2014; Titos et al., 2012, 2014a, 2014b), in the vertical column-integrated atmosphere (e.g., 
Pérez-Ramirez et al., 2013) and in the vertically resolved atmosphere via a lidar system (e.g., Alados-Arboledas et al., 2011; Bravo-Aranda et al, 2015; Córdoba-Jabonero et al., 2011). Nevertheless, details on the sub-micrometric range have not been examined until now in this site. New efforts to fill this data gap were carried out in Granada in recent years, and the primary objective of this work is to report the first aerosol measurements of particle number size distribution in the city of Granada.

Many different sources and atmospheric processes contribute to UFP pollution. Specifically, in urban sites, exhaust and non-exhaust traffic-related emissions are important sources of primary particles and secondary particles (e.g., González and Rodriguez, 2013; Grigoratos and Martini, 2015). Moreover, the topography of Granada favours the accumulation of particles in the cold season due to temperature inversions (Lyamani et al., 2008).

New particle formation (NPF) or nucleation refers to the formation of new atmospheric particles detected at sizes greater than $3 \mathrm{~nm}$, and their subsequent growth to approximately $100 \mathrm{~nm}$ in 1-2 days (Boy and Kulmala, 2002). The mechanisms that influence NPF by nucleation of chemical species or meteorological variables are still uncertain, as reported in the literature (e.g., Kulmala et al., 2012). Other sources that contribute to the UFPs in Granada are fossil fuel (FF) emissions (primary and secondary particles) as a result of traffic activity and biomass burning (BB) (Titos et al., 2017).

Previous studies have developed methodologies to apportion the different source contributions in urban sites (Ma and Birmili, 2015; Rodriguez and Cuevas, 2007). The introduction of new methodologies to separate contributions of sub-micron particles from different sources would be conducive to reducing emissions via action plans.

In recent years, several approaches based on the spectral dependence of the absorption and scattering coefficients were developed in order to identify the sources of aerosols (e.g., Cazorla et al., 2013; Costabile et al., 2013). In particular, Sandradewi et al. (2008) developed an approach based on the spectral dependence of the absorption coefficients for the determination of carbonaceous matter contributions from BB and FF emissions. In this work, special emphasis is carried out to study the impact on the sub-micron particle size distribution for different aerosol sources.

In this study, we analyse the sub-micron particle number measurements obtained in Granada during two spring campaigns and one autumn campaign in 2012-2013. The main goals of this study are (1) to report in detail the physical and chemical characteristics of sub-micron particle number concentrations, (2) to identify for the first time NPF and shrinkage events in Granada and analyse their frequency and physical properties, (3) to introduce a new method for estimating the 
particle number contributions from urban background, traffic, NPF and BB sources and (4) to validate the method introduced in this article by applying different methods for identifying aerosol populations.

\section{Experimental setup}

\subsection{Sampling site}

The city of Granada is located in southeastern Spain $\left(37.16^{\circ} \mathrm{N}, 3.61^{\circ} \mathrm{W}, 680 \mathrm{~m}\right.$ a.s.1.). Granada is a non-industrialized city with a population of approximately 240000 inhabitants (www.ine.es) located in a natural valley at the foot of the Sierra Nevada Mountains. Africa and the Mediterranean basin are approximately $200 \mathrm{~km}$ and $50 \mathrm{~km}$, respectively, to the south. The main local aerosol sources are road traffic and domestic heating during wintertime (e.g., Titos et al., 2017). The main external aerosol source regions affecting the study area are Europe as a major source of anthropogenic pollution and North Africa as a principal source of natural dust (e.g., Lyamani et al., 2008). More information about the site is presented in previous studies (e.g., Lyamani et al., 2008 and references therein).

The IISTA-CEAMA (University of Granada, UGR) sampling station is located in the southern part of the city of Granada in a pedestrian street approximately $100 \mathrm{~m}$ from motor traffic. The main source of traffic emissions for this site is the principal highway of the city located approximately $470 \mathrm{~m}$ to the west. Due to its location, this station is representative of urban background conditions. Air sampling for all the in situ instruments is obtained from the top of a stainless steel tube that is $20 \mathrm{~cm}$ in diameter and $5 \mathrm{~m}$ in length located approximately $15 \mathrm{~m}$ above the ground (695 $\mathrm{m}$ a.s.1.) on the roof of the building (e.g., Lyamani et al., 2008). The UGR station has been in operation since 2005, and it is part of the ACTRIS network (http://actris2.nilu.no/).

\subsection{Aerosol sampling and experimental data}

Measurements reported in this study were collected at an urban background site in Granada in three experimental campaigns. The first spring campaign (SC-1) was performed in the period from $12 / 04 / 2012$ to $26 / 04 / 2012$, the second spring campaign (SC-2) was performed from 22/04/2013 to 09/05/2013, and the autumn campaign (AC) was performed from 16/10/2013 to $14 / 11 / 2013$. The experimental data and the methods used in this study are described in detail below.

\subsubsection{Sub-micron particle number size distribution}

The sub-micron particle number size distribution was monitored with a Scanning Mobility Particle Sizer (SMPS) composed of an Electrostatic Classifier (TSI Mod. 3080) and a Condensation 
Particle Counter (TSI Mod. 3776) with 10-min temporal resolution. Data were obtained within the 16.5-697.8 nm particle mobility diameter range using aerosol and sheath flow rates of 0.3 and 3.0 $1 \mathrm{~min}^{-1}$, respectively. Data were compensated for losses by diffusion and multiple charges with the AIM software (version 9.0.0., TSI, Inc., St Paul MN, USA). Uncertainty in the measured concentration was assumed to be $\pm 10 \%$ from 20 to $200 \mathrm{~nm}$; above this size range, the uncertainty increased to $30 \%$ (Wiedensohler et al., 2012). In this study, the measured particle number concentration was divided into three modes: nucleation mode, $N_{N U C}(16.5-30 \mathrm{~nm})$, Aitken mode, $N_{A I T}(30-100 \mathrm{~nm})$ and accumulation mode, $N_{A C C}(100-697.8 \mathrm{~nm})$. The total particle concentration, $N_{\text {TOT }}(16.5-697.8 \mathrm{~nm})$, is the sum of the three modes. The ultrafine particle mode, UFP (16.5-100), refers to the sum of the nucleation and Aitken modes.

\subsubsection{Aerosol scattering and absorption properties}

Aerosol light scattering and backscattering coefficients, $\sigma_{\mathrm{sp}}$ and $\sigma_{\mathrm{bsp}}$, respectively, were measured with an integrating nephelometer (TSI Mod. 3563) at three wavelengths: 450, 550 and $700 \mathrm{~nm}$. The nephelometer drew the ambient air at a constant flow of $301 \mathrm{~min}^{-1}$ with 5 -min temporal resolution. Nephelometer data were corrected for truncation and non-Lambertian illumination errors using the method described by Anderson and Ogren (1998). The aerosol light absorption coefficient, $\sigma_{a p}$, was measured at 1-min temporal resolution with a Multi-Angle Absorption Photometer (MAAP, Thermo Scientific Mod. 5012) at $637 \mathrm{~nm}$ (Müller et al., 2011). In addition, $\sigma_{a p}$ was measured with an AE31 aethalometer at 1-min temporal resolution (Magee Scientific, Aerosol d.o.o., Mod. AE31) at seven wavelengths - 370, 470, 520, 590, 660, 880 and $950 \mathrm{~nm}$ - in SC-2 and AC campaigns (Hansen and Novakov, 1984). For AE31 data compensation, we used a constant $C_{0}$ value of 3.5 as recommended by ACTRIS (Titos et al., 2017; Zanatta et al., 2016).

The aethalometer drew the ambient air at $41 \mathrm{~min}^{-1}$. Neither absorption nor scattering measurements were performed with an aerosol size cut-off. BC concentrations were estimated at $637 \mathrm{~nm}$ (from MAAP data) and at $880 \mathrm{~nm}$ (from aethalometer data) using mass absorption cross sections of 6.6 $\mathrm{m}^{2} \mathrm{~g}^{-1}$ for MAAP and $16.6 \mathrm{~m}^{2} \mathrm{~g}^{-1}$ for the aethalometer, as recommended by the manufacturer. Aerosol intensive properties, such as single scattering albedo, SSA, scattering Ångström exponent, $S A E$, and absorption Ångström exponent, $A A E$, were calculated from scattering and absorption coefficients as described by Sorribas et al. (2015).

\subsubsection{PM1 and PM10 samples and chemical characterization}

Two high-volume samplers with quartz fibre filters operating at flow rates of $30 \mathrm{~m}^{3} \mathrm{~h}^{-1}$ were used to collect $\mathrm{PM}_{10}(\mathrm{MCV}, \mathrm{CAV}-\mathrm{A} / \mathrm{MSb})$ and $\mathrm{PM}_{1}$ (Digitel DHA-80) samples at the UGR station. 
During SC-1, four 6-h $\mathrm{PM}_{10}$ samples and three 6-h $\mathrm{PM}_{1}$ samples were collected during a single 24-h period (from 24/04/12 to 25/04/12). Due to technical problems, the $\mathrm{PM}_{1}$ filter from hours 915 was not available. In SC-2, three simultaneous 24-h $\mathrm{PM}_{10}$ and $\mathrm{PM}_{1}$ samples were collected (26/04/13, 04/05/13 and 08/05/13). Finally, in AC, three 24-h PM 10 samples (22/10/13, 30/10/13 and 08/11/13) and two 24-h $\mathrm{PM}_{1}$ samples (30/10/13 and 08/11/13) were collected. The 24-h samples started at 07:00 UTC, while the 6-h samples started at 03:00 UTC. A complete chemical analysis was performed for all samples following the procedure of Querol et al. (2001) to determine major and trace elements. The organic carbon (OC) and elemental carbon (EC) mass concentrations were determined by means of a thermo-optical transmission method using a Sunset Laboratory OCEC Analyzer following the EUSAAR2 thermal protocol (Cavalli et al., 2010). An in-depth explanation of the procedure for chemical analysis determination and techniques is given by Querol et al. (2009). PM components were grouped as follows: minerals (sum of $\mathrm{Ca}, \mathrm{Fe}, \mathrm{K}$, $\left.\mathrm{Mg}, \mathrm{CO}_{3}^{=}, \mathrm{SiO}_{2}, \mathrm{Al}_{2} \mathrm{O}_{3}\right)$; sea spray $\left(\mathrm{Na}\right.$, marine $\mathrm{SO}_{4}^{=}$and $\left.\mathrm{Cl}\right)$; $\mathrm{EC}$; $\mathrm{OM}\left(\mathrm{OM}=\mathrm{OC}^{*} 1.6\right)$; secondary inorganic aerosols, SIA ( $\mathrm{NH}_{4}^{+}, \mathrm{NO}_{3}^{-}$and non-marine $\mathrm{SO}_{4}^{=}$); and metals (sum of $\mathrm{Li}, \mathrm{P}, \mathrm{Sc}, \mathrm{Ti}, \mathrm{V}, \mathrm{Cr}$, Mn, Co, Ni, Cu, Zn, Ga, Ge, As, Se, Rb, Sr, Cd, Sn, Sb, Cs, Ba, La, Ce, Lu, Hf, Ta, W, Tl, Pb, Bi, $\mathrm{Th})$.

\subsubsection{Gaseous pollutants and meteorological data}

Data on gaseous pollutants were obtained from the air quality network operated by the Andalusian Regional Government (Consejería de Medio Ambiente, Junta de Andalucía). These data were collected at the Palacio de Congresos air quality monitoring station, which is approximately $1 \mathrm{~km}$ from the IISTA-CEAMA research institute. The air sampling system was located approximately $4 \mathrm{~m}$ above the ground (684 $\mathrm{m}$ a.s.l.) and the instrumentation was located inside an enclosure close to a road with motor traffic (approximately $80 \mathrm{~m}$ from the station). Concentrations of $\mathrm{CO}, \mathrm{NO}_{2}$, $\mathrm{NO}, \mathrm{SO}_{2}, \mathrm{O}_{3}$ and $\mathrm{PM}_{10}$ were measured with 10-min resolution.

Meteorological data were obtained at reference station UGR. Wind speed, ws, and wind direction, $w d$, were measured by a wind monitor (R.M. Young Company, Mod. 05, 103). Temperature, T, was measured with a temperature sensor (ITC, Mod. MTHA1), and relative humidity, $R H$, was measured with a Vaisala sensor. As ancillary information, global solar radiation in the range 340 to $2200 \mathrm{~nm}$ was measured with a pyranometer (Kipp \& Zonen, Mod. CM-11).

\subsubsection{Planetary boundary layer height determination}


Planetary Boundary Layer height $(P B L H)$ was determined using temperature profiles measured at UGR with a Microwave Radiometer (MWR, RPG-HATPRO, Radiometer Physics GmbH) (Navas-Guzmán et al., 2014, Moreira et al., 2018a). The parcel method (Bravo-Aranda et al., 2017; Collaud-Coen et al., 2014; Holzworth, 1964) was used to obtain the PBLH in convective situations (during the day), and the temperature gradient method (Collaud-Coen et al., 2014; Stull, 1988) was employed to obtain the PBLH in stable conditions (during the night) (Moreira et al., 2018a).

\section{Methodology for data analysis}

\subsection{Identification and properties for NPF events}

NPF events were classified into two groups: Class I, which consists of NPF events that are clear and strong with the typical 'banana shape' and whose subsequent formation and growth rates can be easily determined; and Class II, which consists of the rest of the NPF events, i.e., the ones with formation and growth rates that are difficult to evaluate (Dal Maso et al., 2005; Kulmala et al., 2004; Sorribas et al., 2015). Thus, the following procedure was used to classify the NPF events. In the first step, 24-h colour maps were plotted to visualize the particle number evolution to identify possible NPF events. Then, we plotted the temporal evolution of the particle size distributions in the nucleation and Aitken size fractions ( $N_{N U C}$ and $N_{A I T}$, respectively). Additionally, all 10-min particle number size distributions were fitted with a bimodal log-normal function by means of the log-normal distribution function method (Hirsikko et al., 2012) to obtain the geometric mean diameter, $D_{g}$. Therefore, NPF events were identified when $N_{N U C}$ increased more than $1000 \mathrm{~cm}^{-3}$ during at least 1 hour together with an increase in diameter to ensure that the NPF is strong and clear (Sorribas et al., 2015). In this study, we focused on regional nucleation events that show the typical 'banana shape' over several hours (Class I).

The growth rate, $G R$, the formation rate, $J$, and the condensation sink, $C S$, were computed. The $G R$ is defined as the diameter rate of change due to particle population growth (in $\mathrm{nm} \mathrm{h}^{-1}$ ). It was computed using the geometrical mean diameter of the nucleation mode (Eq. 1).

$G R=\Delta D_{g} / \Delta t=\left(D_{g 2}-D_{g 1}\right) /\left(t_{2}-t_{1}\right)$

where $D_{g 1}$ and $D_{g 2}$ are the geometric mean diameters at times $t_{1}$ and $t_{2}$, respectively. The $G R$ was calculated for particle growth within the nucleation size range (GR 16.5-30).

The formation rate is defined as the newly formed particle production rate during a given time (e.g., Dal Maso et al., 2005) with units of $\mathrm{cm}^{-3} \mathrm{~s}^{-1}$. The formation rate was computed for particles in the size bin 16.5-30 $\mathrm{nm}\left(J_{16}\right)$ following Dal Maso et al. (2005) using Eq. 2. 
$J_{16}=d N_{N U C} / d t+F_{\text {coag }}+F_{\text {growth }}=d N_{N U C} / d t+\operatorname{Coag}_{N U C} \cdot N_{N U C}$

where $N_{N U C}$ is the particle concentration in the nucleation size fraction $(16.5-30 \mathrm{~nm}) ; F_{\text {coag }}$ is the loss of particles due to coagulation; and $F_{\text {growth }}$ is the flux of particles out of the size range. Therefore, as particles rarely grow over $30 \mathrm{~nm}$ before a formation event ends, the $F_{\text {growth }}$ can be neglected in Eq. 2 (Dal Maso et al., 2005). The variable $\operatorname{Coag}_{N U C}$ is the coagulation sink of particles in the nucleation size fraction. This variable can be determined using the particle number size distribution and the coagulation coefficient (Dal Maso et al., 2005; Kulmala et al., 2012; Sorribas et al., 2015).

The $C S$ term, which is proportional to the surface area density of an aerosol particle, denotes the ability of the particle size distribution to remove condensable vapour from the atmosphere. The $C S$ values, with units of $\mathrm{s}^{-1}$, are obtained by integrating the measured particle number size distribution according to the method described in Kulmala et al. (2005) and Dal Maso et al. (2005) in Eq. 3.

$C S=2 \pi D \int_{0}^{\infty} D_{p} \beta_{m}\left(D_{p}\right) n\left(D_{p}\right) d D_{p}=2 \pi D \sum_{i} \beta_{m}\left(D_{p, i}\right) D_{p, i} N_{i}$

where $D$ is the diffusion coefficient of the condensing vapour (we used $0.104 \mathrm{~cm}^{2} \mathrm{~s}^{-1}$ for the condensable species $\mathrm{H}_{2} \mathrm{SO}_{4}$ (Kanawade et al., 2011)). The variable $\beta_{m}$ is the transitional correction factor for mass transfer considering a gas vapour molecule mean free path of $123 \mathrm{~nm}$ (Erupe et al., 2010); $D_{p, i}$ is the particle diameter in size section $\mathrm{i}$; and $N_{i}$ is the particle number concentration in the respective section. For this study, the $C S$ was calculated for two periods: (1) from midnight until the hour before the event, $C S_{b}$, and (2) only during growth, $C S_{g}$.

\subsection{Aethalometer model}

Sandradewi et al. (2008) reported that the spectral aerosol absorption depends on the aerosol type. Hence, the particle absorption is wavelength dependent and composition dependent; these facts have led to the development of the 'Aethalometer model'. This model allows the separation of carbonaceous matter from wood and traffic emissions (e.g., Ealo et al. 2016; Harrison et al. 2012) by means of the absorption coefficients $\left(\sigma_{a p}\right)$ and absorption Ångström exponent $(A A E)$. The equations used for this purpose are as follows:

$$
\begin{aligned}
& \sigma_{a p}(370 \mathrm{~nm})_{f f} / \sigma_{a p}(950 \mathrm{~nm})_{f f}=(370 / 950)^{-A A E_{f f}} \\
& \sigma_{a p}(370 \mathrm{~nm})_{b b} / \sigma_{a p}(950 \mathrm{~nm})_{b b}=(370 / 950)^{-A A E_{b b}} \\
& \sigma_{a p}(370 \mathrm{~nm})=\sigma_{a p}(370 \mathrm{~nm})_{f f}+\sigma_{a p}(370 \mathrm{~nm})_{b b} \\
& \sigma_{a p}(950 \mathrm{~nm})=\sigma_{a p}(950 \mathrm{~nm})_{f f}+\sigma_{a p}(950 \mathrm{~nm})_{b b}
\end{aligned}
$$


The absorption values for FF, i.e., $\sigma_{a p}(370 \mathrm{~nm})_{f f}$ and $\sigma_{a p}(950 \mathrm{~nm})_{f f}$, and BB, i.e., $\sigma_{a p}(370 \mathrm{~nm})_{b b}$ and $\sigma_{a p}(950 \mathrm{~nm})_{b b}$, were computed following Eqs. 4-7. Titos et al. (2017) applied this approach and concluded that the most suitable $A A E$ values for $\mathrm{FF}, A A E_{f f}$, and $\mathrm{BB}$, $A A E_{b b}$, were 1.1 and 2 , respectively. Therefore, we obtained the carbonaceous material, $C M$, for FF $\left(C M_{f f}\right)$ and BB $\left(C M_{b b}\right)$ with Eqs. 8-9.

$$
\begin{aligned}
& C M_{f f}=\sigma_{a p}(950 \mathrm{~nm})_{f f} / b(950 \mathrm{~nm}) \\
& C M_{b b}=\sigma_{a p}(370 \mathrm{~nm})_{b b} / b(370 \mathrm{~nm})
\end{aligned}
$$

where $b$ is the mass absorption cross section. More details of the model are described in Sandradewi et al. (2008) and Titos et al. (2017).

\subsection{New method to quantify particle number concentration from different sources}

Previous studies found high correlations between particle number concentration and BC mass concentration in urban environments (e.g., Rodriguez et al., 2007; Rodriguez and Cuevas, 2007). Based on this relationship, we compared the BC mass concentration and the particle number concentration $(\mathrm{N})$ for the three campaigns. Both $\mathrm{BC}$ and $\mathrm{N}$ showed a traffic-related pattern characterized by two simultaneous peaks, one in the morning and the other in the evening (e.g., Lyamani et al., 2011; Patrón et al., 2017). Therefore, the daily particle number values associated with that behaviour were mainly attributed to traffic. However, there were discrepancies between the pattern of BC and N. Specifically, although both BC and N showed two peaks, $\mathrm{N}$ also featured central peaks or elevated particle concentrations from midday to late at night. Hence, by analysing the differences between the daily patterns of $\mathrm{BC}$ and $\mathrm{N}$, we can observe different possible contributions. After analysing the NPF events (Sect. 3.1) and the BB carbonaceous material (Sect. 3.2), the elevated particle number values at midday were attributed to two major contributions: NPF and BB. BB contributions were only present during the second half of the autumn campaign (AC-2) and were evident at midday. Thus, we assumed that the particle number concentration at midday corresponded to BB sources during AC-2 and to NPF during SC-1, SC-2 and AC-1 (first half of the autumn campaign). There was one day in AC-2 with both NPF and BB contributions $(11 / 11 / 13)$, but this day was excluded because it is not possible to distinguish between these contributions with this method.

After comparing the particle number concentration with $\mathrm{BC}, \mathrm{CM}_{\mathrm{ff}}$ and $\mathrm{CM}_{\mathrm{bb}}$ calculated in Sect. 3.2, the variations in particle number size distributions at the UGR station could result from three possible source contributions: (1) 'traffic' (Tr); (2) NPF and (3) BB. The rest of the particle contributions were regarded as 'urban background' (UB), which consists of the contributions 
associated with short-range transport, representing the particles remaining from the diurnal variability during the previous day(s), and the contributions associated with long-range transport of particles from different origins. The proposed method provides an approach to compute the different particle contributions for the total, nucleation, Aitken and accumulation modes found in Granada on a daily basis.

The methodology applied to obtain the source contributions has been carried out by means of different assumptions. It was assumed that each modal particle number concentration, indicated by 'i' (i.e., total, nucleation, Aitken or accumulation), was the sum of the contribution of UB, $\operatorname{Tr}$ and NPF or BB (Eq. 10).

$N_{i}=N_{U B, i}+N_{T r, i}+N_{N P F \text { or } B B, i}$

To obtain the relationship between $\mathrm{N}$ and $\mathrm{BC}$ due to traffic contributions for each day, the following steps were performed:

(Step 1) After comparing the daily patterns of BC and particle number, it was observed that from 23:00-02:00 UTC, both remained nearly constant during the day; thus, it was assumed that negligible contributions were made by the various sources (Tr, NPF and BB) during that period. Therefore, $N_{U B, i}$ and $B C_{U B}$ were averaged for each day during those hours, obtaining one value for each day (this value was quite approximate since daily changes were nearly constant).

(Step 2) From 05:00 to 06:00 UTC, $B C$ and $N_{i}$ concentrations were higher due to traffic activity. In addition, during this period, it was clear that the particle contribution was only due to $\mathrm{Tr}$ and UB contributions. Thus, the particle concentration at that time was averaged for each day and mode: $N_{T r+U B, i}^{5-6}\left(\equiv N_{T r+U B, i}\right)$ and $B C_{T r+U B}^{5-6}\left(\equiv B C_{T r+U B}\right)$.

(Step 3) Finally, to obtain the relationship between $N_{T r, i}$ and $B C_{T r}$, the contributions only due to $\operatorname{Tr}$ were computed from the differences, i.e., $\left(N_{T r+U B, i}-N_{U B, i}\right)$ and $\left(B C_{T r+U B}-B C_{U B}\right)$, obtaining one value per day. Then, for each campaign, the mean daily values of $N_{T r, i}$ and $B C_{T r}$ followed a linear relationship (Eq. 11) with $\mathrm{R}^{2}$ values within the interval [0.80, 0.97].

$N_{T r, i}=N_{T r+U B, i}-N_{U B, i}=m_{i} B C_{T r}=m_{i}\left(B C_{T r+U B}-B C_{U B}\right)$ 
The $B C_{U B}$ and $N_{U B, i}$ values obtained for each day were assumed to be equal during every hour of the day due to the low variability. Then, the hourly $B C_{T r}$ due to traffic was computed by subtracting the hourly $B C_{U B}$ from the hourly experimental $\mathrm{BC}$ since $\mathrm{BC}$ is only due to $\mathrm{Tr}$ and $\mathrm{UB}$.

Once the slope, $m_{i}$, was obtained (one value per campaign and mode; hence, 16 values in total), the $B C$ mass concentration and particle number concentration from the Tr contribution can be computed for each hour by applying Eq. 12, using the hourly $B C_{T r}$ as a tracer element. The intercept was assumed to be zero since it was negligible in comparison with the concentrations obtained. This particle contribution is called the theoretical contribution of the $\operatorname{Tr}$ source, $N_{T r, i}^{\text {the }}$.

$N_{T r, i}^{\text {the }}=m_{i} \cdot B C_{T r}$

Finally, the theoretical contribution to each modal particle concentration from $\mathrm{Tr}$ plus UB sources, $N_{i}^{\text {the }}$, was computed for each hour with Eq. 13.

$N_{i}^{\text {the }}=N_{T r, i}^{\text {the }}+N_{U B, i}$

Both particle number contributions due to NPF and BB $\left(N_{N P F, i}\right.$ and $N_{B B, i}$, respectively) were computed as the difference between the experimental particle number concentration, $N_{i}^{e x p}$, directly obtained by the SMPS data, and the theoretical values, as shown in Eq. 14.

$N_{N P F \text { or } B B, i}=N_{i}^{\text {exp }}-N_{i}^{\text {the }}$

To assess the validity of these assumptions, the relative differences between the experimental concentration, $N_{i}^{\text {exp }}$, and estimated concentration, $N_{i}$ (Eq. 10) considering the four particle source contributions were calculated for each campaign and mode using the equation $\left[\left(N_{i}^{\exp }-N_{i}\right)\right.$. $\left.100 / N_{i}^{e x p}\right]$. The relative differences showed that the particle number concentration computed by means of this approach for each campaign overestimates the mean values of the experimental data by approximately $10-19 \%$ for all modes.

\section{Results and discussion}

\subsection{Overview of the campaigns}

\subsubsection{Physical and chemical characteristics}

Fig. 1 shows box-whisker plots of the hourly average values of the different aerosol properties obtained at the UGR station during the three experimental campaigns. The statistical values of the physical properties are summarized in Table S1.

The particle number concentrations measured in Granada showed large seasonal and inter-annual variability (Fig. 1a). The median ratios of the particle number concentrations for AC to SC-1, AC to SC-2 and SC-1 to SC-2 have been calculated for $N_{N U C}(1.3,1.8,1.4), N_{A I T}(1.7,1.9,1.1)$ and $N_{A C C}(2.4,1.6,0.7)$, respectively. Particle number concentrations in all modes were greater during 
AC than during both spring campaigns, especially in the accumulation mode (Fig. 1a). In addition, the median values of the $N_{N U C}$ and $N_{A I T}$ concentrations were higher during SC-1 than during SC2; however, the $N_{A C C}$ median concentration was greater during SC-2 than during SC-1 and presented higher variability (Fig. 1a). The differences between particle number concentrations obtained during the three campaigns could be associated with the differences in air mass transport, meteorological and synoptic conditions and local anthropogenic emissions.

To compare the levels of particle number concentration at the UGR station with those in other cities, the UFP and $N_{\text {TOT }}$ concentrations were computed. The UFP and $N_{T O T}$ concentrations in Granada were similar to those in Madrid, Vienna and Budapest; lower than those in Pittsburgh, Helsinki, Athens, Amsterdam, Birmingham and Milan; and higher than those in Prague and Rome (Table 1).

The $\sigma_{s p}(550 \mathrm{~nm})$ and $S A E(450-700 \mathrm{~nm})$ values obtained in SC-2 were higher than those obtained in SC-1, indicating increased fine particle contributions to the scattering processes in SC-2 (Fig. 1a). The aerosol light absorption coefficient, $\sigma_{a p}$, had similar median values in both spring campaigns, while these values were doubled in the AC campaign, indicating higher concentrations of absorbing particles in AC than in the spring campaigns (Fig. 1a). The AAE values were approximately 1 in SC-2, which is expected for BC particles, since UGR is an urban background station. In addition, in $\mathrm{AC}$, the $A A E$ values were greater than 1 and exhibited higher variability due to a significant contribution of organic compounds or dust (e.g., Park et al., 2018; Valenzuela et al., 2015). The information on the temporal evolution of all the physical properties discussed above is reported in Fig. S1 in the Supplementary Material.

Figure $1 \mathrm{~b}$ shows the chemical composition of the fine fraction, $\mathrm{PM}_{1}$, for each campaign. The $\mathrm{PM}_{1}$ contributors from highest to lower were as follows: OM, 53-59\%; SIA, 17-30 \%; EC, 11-16 \%; minerals, 2-10\%; and sea spray, 1-6\%. These results were similar to those reported for the same site by Titos et al. $(2012 ; 2014 a)$. Due to the low mass concentration of metals compared with other compounds in the atmosphere, the percentage is negligible. However, metals are a source of information because they exhibit significant correlations with certain size fractions (discussed in Sect. 4.1.2).

The concentrations of major chemical compounds were higher in AC than in both SC-1 and SC2. The compositions of the fine fraction were as follows: 1) the mineral and sea spray fractions were the highest in SC-1;2) the OM and EC fractions were the highest in AC; and 3) the SIA fraction was the highest in SC-2. Notably, in the SIA group, $\mathrm{NO}_{3}^{-}$was predominant in the fine fraction. In addition, the $\mathrm{NH}_{4}^{+}$contribution was also observed in the fine fraction due to its rapid reaction with atmospherically formed sulfuric and nitric acids that contribute to the fine particles 
(Behera and Sharma, 2010). The information on the chemical contributions for each campaign and mode (coarse, $\mathrm{PM}_{10-1}$, fine, $\mathrm{PM}_{1}$ and $\mathrm{PM}_{10}$ ) and during a 1-day intensive monitoring period (6-h filters starting on 24/04/2012 at 03:00 UTC) is reported in Fig. S2 in the Supplementary Material.

\subsubsection{Size-resolved particles vs. chemical composition and air quality parameters}

The particle number concentrations in different size fractions $\left(N_{16.5-20}, N_{20-30}, N_{30-50}, N_{50-100}, N_{100-}\right.$ 200, $N_{200-300,} N_{300-400}$, and $N_{400-697.8}$ ) were correlated with (1) the chemical composition of the $\mathrm{PM}_{1}$ filters and (2) the air quality parameters. Table 2 shows the Pearson's correlation coefficients, r, between the particle number concentrations in different size fractions and the chemical compounds (mineral, sea spray, OM, EC, SIA and metals) on the left and the air quality parameters $\left(\mathrm{CO}, \mathrm{NO}_{2}\right.$, $\mathrm{NO}, \mathrm{SO}_{2}, \mathrm{O}_{3}, \mathrm{PM}_{10}$ and $\mathrm{BC}$ ) on the right. Particle number concentrations were averaged for the same timeframes of (1) 24 and 6 hours and (2) 1-h resolution for all the campaigns since there were no significant differences in the correlation coefficients among the individual campaigns.

\section{Chemical composition}

Particle number concentration was measured in the interval $16.5-697.8 \mathrm{~nm}$, whereas $\mathrm{PM}_{1}$ includes particles with diameters less than $1 \mu \mathrm{m}$. Thus, particles in the range $0.6978-1 \mu \mathrm{m}$ are not counted in the particle number concentration. However, the count can be considered representative since the number of particles within the range $0.6978-1 \mu \mathrm{m}$ is low in comparison with the number concentration of particles with smaller diameters. Minerals and metals did not show significant correlations as groups (Table 2, left). However, some of the compounds or elements within these chemical groups correlated significantly at the 0.05 confidence level with certain size fractions (see Table S2 in the Supplementary Material). For this reason, correlations with particle number size-resolved distributions will be discussed as either groups of chemical compounds or individual elements.

Certain individual elements of the mineral group presented significant correlations with the number concentration in $N_{16.5-20}(\mathrm{Fe}), N_{30-50}\left(\mathrm{CO}_{3}{ }^{2-}\right), N_{50-100}(\mathrm{~K})$ and $N_{100-300}(\mathrm{Ca})$. The mineral compounds in the fine fraction are likely to originate in mineral dust via local transport in Granada (Titos et al., 2014a). Moreover, mineral components (except Fe) normally correlate with particle numbers in the Aitken or accumulation modes. This pattern is consistent with the fact that particles in the upper range of the fine fraction are related to re-suspension processes. 
The metal group in the fine fraction was also related to road dust sources (Titos et al., 2014a). Within this group, the elements normally correlated with the nucleation size fraction $\left(N_{16.5-20}\right)$, such as Fe, V, Mn, Sr, Sb, La and Ce, might originate from brake or vehicle wear (e.g., Adachi and Tainosho, 2004; Alves et al., 2015; Apeagyei et al., 2011; Harrison et al., 2003, 2012; Keuken et al., 2010; Mbengue et al., 2014; Sternbeck et al., 2002; Wahling et al., 2006). These elements are therefore traffic-influenced aerosols, and their particle number size distribution is predominantly in the low range of the fine fraction (Morawska et al., 1999). However, other elements, similar to those discussed above, are correlated with particle number in $N_{16.5-30}(\mathrm{Cr}$ and Hf), $N_{20-50}(\mathrm{Cu}), N_{30-100}(\mathrm{Zn}$ and $\mathrm{Rb}), N_{100-400}(\mathrm{As}), \mathrm{N}_{>50}(\mathrm{~Pb}$ and $\mathrm{Nb}), N_{>100}(\mathrm{Zr})$ and $N>400(\mathrm{Sn}$ and Y). All of these elements mainly originate from the wearing of vehicle brakes via abrasion rather than from combustion.

The OM correlated significantly with the particle number in the Aitken and accumulation modes, and the EC correlated with all modes. The possible explanation is the following. OM is normally related to $\mathrm{BB}$ emissions, and $\mathrm{EC}$ is normally related to FF emissions. In addition, the EC presents similar correlations with BC since both are traffic-related particles (Table 2). In Sect. 4.2.2, the contribution of different sources to the different particle number modes in the fine fraction is given. The results show that $\mathrm{BB}$ (proportional to $\mathrm{OM}$ ) presents higher particle number concentrations in the Aitken and accumulation modes, while $\operatorname{Tr}$ (proportional to EC) is a major contributor in all modes (Fig. 3).

The SIA group is composed mainly of sulfate, ammonia and nitrate. Sulfate and ammonia correlated significantly (positively and negatively, respectively) with $N_{30-50}$. Nitrate correlated with the Aitken and accumulation modes $(N>50)$. Therefore, SIA compounds correlated with the upper range of the fine fraction and may be related to particles originating from regional re-circulation (Titos et al., 2014a).

\section{Air quality variables}

The correlation among particle number size distributions and mass concentrations of different pollutants offers some insight into the origins of the particles in the different size ranges. Table 2 (right) summarizes the Pearson's correlation coefficients among particle number concentrations and gaseous pollutants for all the campaigns. The $\mathrm{CO}, \mathrm{NO}_{2}, \mathrm{NO}$ and $\mathrm{BC}$ exhibited similar behaviours, i.e., high and moderate correlations with particle numbers in all modes. In particular, $\mathrm{NO}_{2}$ and $\mathrm{CO}$ showed stronger correlations for $N_{20-200}$ and $N>400$; NO showed a stronger correlation for 30-100 $\mathrm{nm}$ than for the smallest particles; and $B C$ showed the highest correlation for $N_{30-100}$ (Aitken mode). These pollutants are related to traffic exhaust; thus, the results confirmed the strong 
relationship between pollutant emissions and fine particles (from nucleation mode and subsequent modes), which results in adverse effects on human health. This result corroborates previous finding showing that elevated concentrations of local $\mathrm{NO}_{\mathrm{x}}$ and $\mathrm{CO}$ where associated with the local vehicular traffic peak hours (Rahman et al., 2017).

The $\mathrm{SO}_{2}$ emissions present moderate correlations with particle number for $N_{>50}$ (Table 2-right). This secondary pollutant can be oxidized to sulfuric acid, which can condense on particles and increase their size from a few nanometres to larger diameters within the accumulation mode.

Moderate negative correlations were found between $N_{16.5-100}$ and $\mathrm{O}_{3}$. This result suggests an inverse relationship between particle number concentration and ozone, possibly indicating that the two have opposite diurnal cycles. Finally, $\mathrm{PM}_{10}$ presents higher correlations with particle number in the upper range of sub-micron particles.

\subsection{Diurnal patterns}

\subsubsection{Characterization of NPF events}

During SC-1, SC-2 and AC, the number of NPF events (frequency) were 3 (21.4\%), 6 (35.3\%) and $2(6.9 \%)$, respectively (Table 3$)$. The higher frequency in spring than in autumn is a common feature in many European cities (Manninen et al., 2010). The higher frequency of NPF during the spring campaigns in Granada might be explained by the higher amount of biogenic precursor gases and higher photochemical activity in spring than in autumn.

Elevated pre-existing particles can decrease aerosol nucleation by scavenging newly nucleated particles and condensable vapour (Sorribas et al., 2015). Thus, higher CS results in lower formation rates, $J_{16}$. Because of the higher concentration of particles during autumn than during spring (Fig. 1), $J_{16}$ reached its lowest value during $\mathrm{AC}$, when the $C S$ before the event, $C S_{b}$, was higher. Therefore, the reason for the less frequent NPF events in autumn is likely because $C S$ values are higher in autumn than in spring.

The $G R_{16.5-30}$ values obtained were in the range $1.75-7.45 \mathrm{~nm} \mathrm{~h}^{-1}$, with similar values in both spring campaigns and lower values in autumn (due to the higher $C S_{g}$ values in $\mathrm{AC}$, Table 3). Therefore, the lower $C S_{g}$ values and the higher concentration of precursor gases during the spring (due to biogenic emissions) may enhance particle growth and explain the higher $G R_{16.5-30}$ values observed in the spring campaigns.

During SC-1, there was one 'shrinkage event' that lasted 2:10 h. The minimum $D_{g}$ reached was 19 $\mathrm{nm}$. The shrinkage rate, which is calculated similarly to $G R_{16.5-30}$ (negative value), was $-2.5 \mathrm{~nm} \mathrm{~h}^{-}$ 
1. This value was similar to that reported by Salma et al. (2016) for an urban site in Budapest (with values ranging from -4.8 to $-2.3 \mathrm{~nm} \mathrm{~h}^{-1}$ ). Until now, the causes of shrinkage processes are unknown. Some explanations are based on changes in meteorological conditions or atmospheric vertical mixing, which lead to evaporation of previously condensed volatile and semi-volatile species from the particulate phase to the gas phase (Skrabalova et al., 2015; Yao et al., 2010).

During atmospheric stagnation episodes, the accumulation of gas precursors might enhance the nucleation processes. A period with high pressure over the Iberian Peninsula and low pressure over the Atlantic Ocean led to atmospheric stagnation conditions over the Iberian Peninsula. By analysing the synoptic maps (not shown) corresponding to the three campaigns, a four-day stagnation period occurred from 6 to 9 May 2013 (in SC-2). Furthermore, one NPF event occurred each day from 7 to 9 May (Fig. 2). Some general features for all of the days were (1) a higher particle number concentration during the traffic rush hours (approximately 08:00 and 19:00 UTC) (Fig. 2a) and (2) mountain-valley breezes, i.e., wind coming from the east (mountains) at night and from the west (valley) during the day (Fig. 2c). The mountain breezes might have brought biogenic precursor gases from the mountains during the night, resulting in a subsequent increase in particle number when the sun rose. Similarly, Rahman et al., (2017) found that the $w d$ pattern indicated the transport of precursors from different sources.

During the last three days, the particle number concentration and $D_{g}$ increased at approximately midday (Fig. 2a), indicating the growth of freshly nucleated particles. In addition, the maximum and minimum $T$ were $\sim 4{ }^{\circ} \mathrm{C}$ higher (between 14 to $25 \%$ ) than that of the first day. Additionally, the maximum $R H$ values at night during NPF events were, on average, $14 \%$ lower than on the day without an event (Fig. 2b).

Figure $2 \mathrm{~d}$ shows the experimental global irradiance (black lines) together with the empirical total solar irradiance calculated for cloud-free conditions (red line). Following the procedure described in Piedehierro et al. (2014), the uncertainty lines of the modelled radiation were plotted in order to recognize the radiation 'enhancement' events that occur when the experimental radiation surpasses the upper uncertainty (upper red-dashed line) of the modelled radiation due to the presence of broken cloud fields close to the sun favouring reflections of solar radiation on the sides of the broken clouds. On the non-event day, the enhancement is slight, while on the following three days, the enhancement events are strong. Thus, strong global solar irradiance enhancements might have increased the photochemical activity that led to the NPF during the last three days. However, this phenomenon should be studied in more detail in future studies.

\subsubsection{Particle source contribution}


The results obtained for each type of contribution after applying the methodology described in Sect. 3.3, are presented below.

- UB contribution

The total number particle concentration for $\mathrm{UB}, N_{U B, T O T}$, during the autumn campaign (AC-1 and AC-2) was on average ( \pm SD) $7800 \pm 3000 \mathrm{~cm}^{-3}$, while in both spring campaigns (SC-1 and SC2), it was $5000 \pm 2300 \mathrm{~cm}^{-3}$, i.e., $36 \%$ lower. Previous studies carried out in Granada showed that during the cold season, there was an increase in anthropogenic emissions in combination with lower mixing layer heights (Granados-Muñoz et al., 2012). Given that the particle number in the Aitken mode was predominantly associated with the UB source, $N_{U B, A I T}$ was examined in detail. Large differences in $N_{U B, A I T}$ existed between spring (SC-1: $2600 \pm 1700 \mathrm{~cm}^{-3}$; SC-2: $2300 \pm 1000$ $\mathrm{cm}^{-3}$ ) and autumn (AC-1: $3400 \pm 1400 \mathrm{~cm}^{-3}$; AC-2: $\left.4400 \pm 2100 \mathrm{~cm}^{-3}\right)$. However, $B C_{U B}$ was the same in both spring campaigns $\left(\sim 700 \mathrm{ng} \mathrm{m}^{-3}\right)$ but higher in autumn $\left(\sim 1500\right.$ and $1800 \mathrm{ng} \mathrm{m}^{-3}$ in AC-1 and AC-2, respectively). Thus, differences between seasons might be explained by the lower emissions and higher $P B L H$ during spring (leading to greater mixing) than during autumn (Granados-Muñoz et al., 2012; Moreira et al., 2018a, 2018b), when the PBLH is $56 \%$ lower. In particular, the higher concentration of particles during AC-2 might be related to the $\mathrm{BB}$ contribution along with a shallower $P B L H$ (Fig. 3a), which reduced the vertical mixing and thus favoured the accumulation of particles in the surface layer.

- $\quad$ Tr contribution

The diurnal pattern of traffic contribution shows two peaks (see Fig. 3 e-p red bars) that coincide with traffic rush hours. The peak in the evening (19:00 UTC) is lower than that in the morning (08:00 UTC), as seen in previous studies for $B C$ (e.g., Lyamani et al., 2011). In general, the particle number concentrations due to traffic were more than $50 \%$ higher in autumn than in spring and reached the highest values in AC-2. According to the contributions of different $\mathrm{Tr}$ sources to the different particle modes, the nucleation mode is likely to contain particles from primary emissions from traffic exhaust sources and/or non-exhaust sources, such as brake wear (see Sect. 4.1.2.). The results are in agreement with those obtained by Rahman et al. (2017) and Hama et al. (2017) who found that the total particle number was dominated by the nucleation and Aitken modes. Traffic particles in the Aitken and accumulation modes probably come from the same source as the traffic exhaust-related gases, such as $\mathrm{CO}, \mathrm{NO}_{2}, \mathrm{NO}$ and $\mathrm{BC}$ (see Sect. 4.1.2.).

- NPF contribution 
During the spring campaigns, when NPF events occurred, the number size distribution for the NPF contribution in the nucleation mode, $N_{N P F, N U C}$, presented on average $1300 \pm 1200 \mathrm{~cm}^{-3}$. For AC-1, the particle number was $25 \%$ less than that of the spring campaigns. Normally, the NPF events started at approximately 12:00 UTC and finished at 21:00 UTC (Fig. 3 i, and k) because of the higher photochemical activity during the most intense hours of sun. The higher particle number during the middle of the day which is associated with NPF events is consistent with previous studies in urban environments (e.g., Kulmala and Kerminen, 2008; Rahman et al., 2017). However, the NPF started at 11:00 UTC in SC-2 (Fig. 3 j), possibly due to earlier atmospheric mixing after sunrise during SC-2 than during the other campaigns, and was associated with $P B L H$ behaviour (Fig. 3 b). Note that the PBLH percentiles peaked at 12:00 UTC in SC-2, while during SC-1 and AC-1, they peaked at 15:00 and 14:00 UTC, respectively (see Fig. 3 a-c); thus, the PBLH might influence the start of NPF events.

\section{- BB contribution}

BB events occurred during the entire SC-2 period. The highest particle number concentration was in the Aitken mode, followed by the accumulation and nucleation modes (Fig. 3, 1, p, t). Hu et al. (2014) found that BB can produce higher levels of UFPs compared to Tr emissions although Rahman et al. (2017) did not find such activity. In AC-2, the differences between the peaks in the morning and evening were less than $10 \%$, probably due to the occurrence of BB and the smaller increase in the $P B L H$ during autumn.

\subsection{Application of different approaches for aerosol typing}

This section links the aerosol optical properties, the chemical composition and the estimated particle number concentrations computed with the approach proposed in Sect. 3.3.

Costabile et al. (2013) and Cazorla et al. (2013), (henceforth COS and CAZ, respectively), proposed different approaches to classify aerosol populations based on their spectral optical properties: absorption and scattering. Both approaches take into account the strong relationships between $S A E$ and particle size and between $A A E$ and chemical composition. In addition, SSA is a function of the scattering and absorption coefficients; thus, variations in the aerosol type might result in different SSA values for urban pollutants or BB particles (Bergstrom et al., 2007).

COS devised a paradigm based on scattering and absorption Ångström exponents, SAE (467-660), $A A E$ (467-660), and $S S A$ variations ( $\left.d S S A=S S A_{660}-S S A 467\right)$. This scheme allowed the classification of aerosol populations by their predominant mode in a 'region'. CAZ proposed a classification 
scheme called the 'Ångström matrix' based on $A A E$ (440-675) and SAE (440-675) for classifying the absorbing aerosol species and their mixtures. Both methods have been applied to confirm the presence of particles with BB and FF origins obtained by means of the approach described in Sect. 3.2 during $\mathrm{AC}$ (for FF) and AC-2 (for BB). The pair of wavelengths used in this study are 450$660 \mathrm{~nm}$ for $A A E, S A E$ and $d S S A$ since these wavelengths are close to those used in both approaches. Figure 4 links three types of information: 1) the classification scheme presented in COS, i.e., values of $d S S A(660-450)^{\cdot} A A E(450-660)$ and $S A E(450-660)$ are placed on the $\mathrm{X}$ and $\mathrm{Y}$ axes, respectively, and $S S A(530)$ is indicated with shaded areas in both panels; 2) the carbonaceous material apportionment of $C M_{f f}$ and $C M_{b b}$ (upper and lower panels, respectively) indicated in the colour scale and computed in Sect. 3.2; and 3) the estimated particle number concentrations $N_{N U C, T r}$ and $N_{A C C, B B}$ (upper and lower panels, respectively) computed in Sect. 3.3, indicated by dot size. The $N_{N U C, T r}$ and $N_{A C C, B B}$ concentrations are used since changes in dot size are more noticeable in those modes for $\operatorname{Tr}\left(C M_{f f}\right)$ and $\mathrm{BB}\left(C M_{b b}\right)$, respectively, during AC (see Fig. 3).

The inverse relationship between $S A E$ (450-660) and $d S S A(660-450) \cdot A A E$ (450-660) is due to the common dependence of $S A E$ and $A A E$ with $A S S A$ on particle size and composition, respectively. Thus, a negative slope exists regardless of the particle's composition since scattering decreases faster than absorption with decreasing particle diameter.

In COS, the biomass burning smoke mode (BBM in COS or BB in the present work) was in the region $-0.15<d S S A 660-450^{\circ} A A E_{450-660}<0.1, S A E_{450-660}>1.5$ with $S S A>0.8$, while the soot mode (STM in COS or FF in the present work) was in the region $-0.2<d S S A_{660-450} \cdot A A E_{450-660}<0.2,0<$ $S A E_{450-660}<3$ with $S S A<0.8$. The dark-red dots in Fig. 4a correspond to FF, while those in Fig. $4 \mathrm{~b}$ correspond to $\mathrm{BB}$. Hence, the regions predicted in COS are consistent with the presence of BB and FF obtained by applying the Aethalometer model and the approach presented in this study. By using the 'Ångström matrix' proposed in CAZ, which shows the dominant $A A E$ vs. SAE regions, the same results were obtained, i.e., the $C M_{b b}$ maxima correspond to the 'OC-dominated' region, while the $C M_{f f}$ maxima correspond to the 'EC-dominated' region (not shown).

Based on the dot size in Fig. 4, the higher particle number concentrations in Fig. 4a are due to FF carbonaceous matter, while the higher particle number concentrations in Fig. $4 \mathrm{~b}$ are due to BB (both in dark-red). Moreover, the larger dots indicate higher particle number concentrations. Thus, the approach proposed in this paper (Sect. 3.3) to estimate the particle number contributions is consistent with the $C M_{b b}$ and $C M_{f f}$ maxima computed by means of the Aethalometer model (Sect. 3.2) and with both models described in COS and CAZ that combine the spectral variations with the predominant aerosol populations. 


\section{Conclusions}

Aerosol particles in the submicron size fraction have been investigated during three intensive campaigns at an urban background station (Granada, Spain). The physicochemical characteristics were studied during two spring campaigns (SC-1 and SC-2) and one autumn campaign (AC).

The particle number concentration was correlated with the chemical composition of $\mathrm{PM}_{1}$ and the air quality parameters for different size fractions. Particle number in the Aitken and accumulation modes exhibited a traffic-related behaviour. Therefore, particles in those size fractions may be mainly influenced by (1) direct traffic emissions in each separate mode and/or (2) the particle growth from diameters within the Aitken mode to the accumulation mode. Furthermore, the results are consistent with the predominance of carbonaceous material associated with $\mathrm{BB}$ and FF (directly related to $\mathrm{OM}$ and $\mathrm{EC}$, respectively) in these modes.

For the first time, NPF events in Granada were shown to have a higher frequency and particle growth rate $\left(G R_{16.5-30}\right)$ in spring than in autumn. The growth started at approximately midday with $G R_{16.5-30}$ variations in the range $1.75-7.45 \mathrm{~nm} \mathrm{~h}^{-1}$. In addition, one shrinkage event was observed, with a particle shrinkage rate of $-2.5 \mathrm{~nm} \mathrm{~h}^{-1}$. During a period of atmospheric stagnation conditions from 7 to 9 May 2013, three consecutive NPF events occurred in association with mountain breezes. This behaviour was associated with lower $R H$ values and higher $T$ and radiation values with respect to the first day, where no NPF occurred.

A new approach was introduced to estimate the particle number contributions using black carbon concentration as a tracer, based on previous data analysis of the three campaigns. The variations in particle number size distribution could result from UB, Tr, NPF and BB sources. Moreover, the results showed that the particle number concentration in the Aitken mode was predominantly associated with UB and Tr; the particle concentration in the nucleation mode was associated with NPF, and the particle concentration in the accumulation mode was associated with BB. Additionally, the particle number in all modes was higher in autumn than in spring, possibly due to the lower $P B L H$, which favoured the accumulation of particles.

Finally, based on the Aethalometer model, the BB and FF contributions were computed and compared with two different approaches for classifying aerosol populations and with the approach proposed in this article. The comparison of the four approaches, based on spectral properties, the estimated particle number concentration and chemical species, showed successful agreement among the results.

\section{Acknowledgments}


This work was supported by the Andalusian Regional Government through project P12-RNM2409; by the Spanish Ministerio de Economía y Competitividad (MINECO) under grants CGL2014-55230-R, CGL2013-45410-R, CGL2016-81092-R and TEC2015-63832-P; by the ACTRIS (Aerosols, Clouds, and Trace Gases Research Infrastructure Network) Research Infrastructure Project funded by the European Union's Horizon 2020 research and innovation programme (grant agreement n. 654109); and EFRD (European Fund for Regional Development). A. del Águila appreciates the MINECO support (Programa de Ayudas a la Promoción del Empleo Joven e Implantación de la Garantía Juvenil en i+D+i) under grant PEJ-2014-A-52129.

\section{References}

Adachi, K. and Tainosho, Y., 2004. Characterization of Heavy Metal Particles Embedded in Tire Dust. Environmental International, 30, 1009-1017.

Alados-Arboledas, L., Müller, D., Guerrero-Rascado, J.L., Navas-Guzmán, F., Pérez-Ramírez, D., Olmo, F.J., 2011. Optical and microphysical properties of fresh biomass burning aerosol retrieved by Raman lidar, and star- and sun-photometry. Geophys. Res. Lett. 38, L01807.

Altaratz, O., Koren, I., Remer, L.A., Hirsch, E., 2014. Review: Cloud invigoration by aerosols-Coupling between microphysics and dynamics. Atmospheric Research 140-141, 38-60, https://doi.org/10.1016/j.atmosres.2014.01.009.

Alves, C., Gomes, J., Nunes, T., Duarte, M., Calvo, A., Custódio, D., Pio, C., Karanasiou, A., Querol, X., 2015. Size-segregated particulate matter and gaseous emissions from motor vehicles in a road tunnel. Atmospheric Research 153, 134-144, https://doi.org/10.1016/j.atmosres.2014.08.002

Anderson, T. L., Ogren, J. A., 1998. Determining aerosol radiative properties using the TSI 3563 integrating nephelometer. Aerosol Sci. Technol. 29, 57-69.

Apeagyei, E., Bank, M.S., Spengler, J.D., 2011. Distribution of heavy metals in road dust along an urbanrural gradient in Massachusetts. Atmospheric Environment 45, 2310-2323.

Behera, S. N., Sharma, M., 2010. Investigating the potential role of ammonia in ion chemistry of fine particulate matter formation for an urban environment. Sci. Total Environ. 408, 3569-3575. 
Bergstrom W., Pilewskie P., Russel P., Redemann J., Bond T., Quinn P., Sierau B., 2007. Spectral absorption properties of atmospheric aerosols, Atmos. Chem. Phys., 7, 5937-5943.

Borsós, T., Rimnacova, D., Zdimal, V., Smolik, J., Wagner, Z., Weidinger, T., Burkart, J., Steiner, G., Reischl, G., Hitzenberger, R., Schwarz, J., Salma, I., 2012. Comparison of particulate number concentrations in three Central European capital cities. Sci. Total Environ. 433, 418-426.

Boy, M., Kulmala, M., 2002. Nucleation events in the continental boundary layer: influence of physical and meteorological parameters. Atmos. Chem. Phys. 2, 1-16.

Bravo-Aranda, J.A., Titos, G., Granados-Muñoz, M.J., Guerrero-Rascado, J.L., Navas-Guzmán, F., Valenzuela,A., Lyamani, H., Olmo, F.J., Andrey, J., Alados-Arboledas, L., 2015. Study of mineral dust entrainment in the planetary boundary layer by lidar depolarization technique, Tellus B: Chemical and Physical Meteorology, 67:1, 26180, doi:10.3402/tellusb.v67.26180

Bravo-Aranda, J. A., de Arruda Moreira, G., Navas-Guzmán, F., Granados-Muñoz, M. J., GuerreroRascado, J. L., Pozo-Vázquez, D., Arbizu-Barrena, C., Olmo Reyes, F. J., Mallet, M., Alados Arboledas, L. 2017. A new methodology for PBL height estimations based on lidar depolarization measurements: analysis and comparison against MWR and WRF model-based results, Atmos. Chem. Phys., 17, 68396851, https://doi.org/10.5194/acp-17-6839-2017.

Brines, M., Dall’Osto, M., Beddows, D. C. S., Harrison, R. M., Gómez-Moreno, F., Núñez, L., Artíñano, B., Costabile, F., Gobbi, G. P., Salimi, F., Morawska, L., Sioutas, C., Querol, X., 2015. Traffic and nucleation events as main sources of ultrafine particles in high-insolation developed world cities. Atmos. Chem. Phys. 15, 5929-5945.

Cazorla, A., Bahadur, R., Suski, K.J., Cahill, J.F., Chand, D., Schmid, B., Ramanathan, V., Prather, K.A., 2013. Relating aerosol absorption due to soot, organic carbon, and dust to emission sources determined from in-situ chemical measurements. Atmos. Chem. Phys. 13, 9337-9350.

Cavalli, M., Viana, M. Yttri, K.E., Genberg, J., Putaud, J.-P., 2010. Toward a standardized thermal-optical protocol for measuring atmospheric organic and elemental carbon: the EUSAAR Protocol. Atmos. Meas. Tech., 3, 79-89.

Collaud-Coen, M., Praz, C., Haefele, A., Ruffieux, D., Kaufmann, P., Calpini, B., 2014. Determination and climatology of the planetary boundary layer height above the Swiss plateau by in situ and remote sensing measurements as well as by the COSMO-2 model. Atmos. Chem. Phys. 14, 13205-13221. 
Córdoba-Jabonero, C., Sorribas, M., Guerrero-Rascado, J. L., Adame, J. A., Hernandez, Y., Lyamani, H., Cachorro, V., Gil, M., Alados-Arboledas, L., Cuevas, E., de la Morena, B., 2011. Synergetic monitoring of Saharan dust plumes and potential impact on surface: a case study of dust transport from Canary Islands to Iberian Peninsula. Atmos. Chem. And Phys. 11, 3067-3091. doi: 10.5194/acp-11-3067-2011.

Costabile, F., Barnaba, F., Angelini, F., Gobbi, G.P., 2013. Identification of key aerosol populations through their size and composition resolved spectral scattering and absorption. Atmos. Chem. Phys. 13, 2455-2470.

Dal Maso M., Kulmala M., Riipinen I., Wagner R., Hussein T., Aalto P. P., Lehtinen K. E. J., 2005. Formation and growth of fresh atmospheric aerosols: eight years of aerosol size distribution data from SMEAR II, Hyytiälä, Finland. Boreal Env. Res. 10, 323-336.

Delfino R.J., Sioutas C., Malik S., 2005. Potential role of ultrafine particles in associations between airborne particle mass and cardiovascular health. Environ Health Perspect. 113, 934-946.

Ealo, M., Alastuey, A., Ripoll, A., Pérez, N., Minguillón, M.C., Querol, X., Pandolfi, M., 2016. Detection of Saharan dust and biomass burning events using near real-time intensive aerosol optical properties in the northwestern Mediterranean. Atmos. Chem. Phys. 16, 12567-12586.

Erupe, M. E., Benson, D.R., Li, J., Young, L.-H., Verheggen, B., Al-Refai, M., Tahboub, O., Cunningham, C., Frimpong, F., Viffiano, A.A. and Lee, S.-H., 2010. Correlation of aerosol nucleation rate with sulfuric acid and ammonia in Kent, Ohio: An atmospheric observation, J. Geophys. Res., 115, D23216, doi:10.1029/2010JD013942.

Esteve, A. R., Estellés, V., Utrillas, M.P., Martínez-Lozano, J.A., 2014. Analysis of the aerosol radiative forcing over a Mediterranean urban coastal site. Atmospheric Research 137, 195-204.

González, Y., Rodríguez, S., 2013. A comparative study on the ultrafine particle episodes induced by vehicle exhaust: A crude oil refinery and ship emissions. Atmospheric Research 120-121, 43-54, https://doi.org/10.1016/j.atmosres.2012.08.001.

Granados-Muñoz, M., Navas-Guzmán, F., Bravo-Aranda, J., Guerrero-Rascado, J., Lyamani, H., Fernández-Gálvez, J., Alados-Arboledas, L., 2012. Automatic determination of the planetary boundary layer height using lidar: One-year analysis over southeastern Spain. J. Geophys. Res. Atmos. 117, D18208, doi:10.1029/2012JD017524. 
Grigoratos T., Martini G., 2015. Brake wear particle emissions: a review. Environ. Sci. Pollut. Res. 22:2491. https://doi.org/10.1007/s11356-014-3696-8.

Hama, M. L., Cordell, R. L., Kos, G.P.A, Weijers, E.P., Monks, P.S., 2017. Sub-micron particle number size distribution characteristics at two urban locations in Leicester. Atmospheric Research 197, 1-16, https://doi.org/10.1016/j.atmosres.2017.04.021

Hansen, A.D.A., Novakov, R., 1984. The Aethalometer - an instrument for the real-time measurement of optical absorption by aerosol particles. Sci. Total Environ. 36, 191-196.

Harrison, R.M., Tilling, R., Romero, M.S.C., Harrad, S., Jarvis, K., 2003. A study of trace metals and polycyclic aromatic hydrocarbons in the roadside environment. Atmospheric Environment 37, 2391-2402.

Harrison, R.M., Jones, A.M., Gietl, J., Yin, J., Green, D.C., 2012. Estimation of the contributions of brake dust, tire wear, and resuspension to non-exhaust traffic particles derived from atmospheric measurements. Environmental Science and Technology 46, 6523-6529.

Hirsikko, A., Vakkari, V., Tiitta, P., Manninen, H.E., Gagné, S., Laakso, H., Kulmala, M., Mirme, A., Mirme, S., Mabaso, D., Beukes, J.P., Laakso, L., 2012. Characterization of sub-micron particle number concentrations and formation events in the western Bushveld Igneous Complex, South Africa. Atmos. Chem. Phys. 12, 3951-3967.

Holzworth, C. G.: Estimates of mean maximum mixing depths in the contiguous United States, Mon. Wea. Rev., 92, 235-242, 1964.

Hu, J., Zhang, H., Chen, S., Ying, Q., Wieinmyier, C., Vandenberghe, F., Kleeman, M. J., 2014. Identifying PM2.5 and PM0.1 sources for Epidemiological studies in California. Environ. Sci. Technol. 48 (9), 49804990, 10.1021/es404810z

IPCC, 2013. Fifth Assessment Report of the Intergovernmental Panel on Climate Change. Cambridge University Press, Cambridge, NY, USA. Contribution of working group I.

Kanawade, V.P., Jobson, B.T., Guenther, A.B., Erupe, M.E., Pressley, S.N., Tripathi, S.N., and Lee, S.-H., 2011. Isoprene suppression of new particle formation in a mixed deciduous forest. Atmos. Chem. Phys., 11, 6013-6027. 
Keuken, M., Denier van der Gon, H., van der Valk, K., 2010. Non-exhaust emissions of PM and the efficiency of emission reduction by road sweeping and washing in the Netherlands. Science of the Total Environment 408:4591-4599

Kulmala, M., Kerminen, V., 2008. On the formation and growth of atmospheric nanoparticles. Atmospheric Research 90, 132-150, https://doi.org/10.1016/j.atmosres.2008.01.005

Kulmala, M., Petäjä, T., Mönkkönen, P., Koponen, I. K., Dal Maso, M., Aalto, P. P. Kerminen, V.-M., 2005. On the growth of nucleation mode particles: Source rates of condensable vapor in polluted and clean environments. Atmos. Chem. Phys., 5, 409-416.

Kulmala, M., Petäjä T., Nieminen, T., Sipilä, M., Manninen, H.E., Lehtipalo, K., Dal Maso, M., Aalto, P.P., Junninen, H., Paasonen, P., Riipinen I., Lehtinen, K.E.J., Laaksonen, A. and Kerminen, V.-M., 2012. Measurements of the nucleation of atmospheric aerosol particles. Nature Protocols, Vol. 7, $\mathrm{N}^{\circ} .9$.

Kulmala, M., Vehkamäki, H., Petäjä, T., Dal Maso, M., Lauri, A., Kerminen, V. M., Birmili, W., McMurry, P. H., 2004. Formation and growth rates of ultrafine atmospheric particles: A review of observations. J. Aerosol Sci. 35, 143-176.

Lightly, J.S., Veranth, J.M., Sarofim, A.F., 2011. Combution aerosols: Factors Governing their size and composition and implications to human health. Journal of the air \& waste management association, 15651618, doi: 10.1080/10473289.2000.10464197.

Lyamani, H., Olmo, F.J., Alados-Arboledas, L., 2008. Light scattering and absorption properties of aerosol particles in the urban environment of Granada, Spain. Atmos. Environ. 42, 2630-2642.

Lyamani, H., Olmo, F.J., Alados-Arboledas, L., 2010. Physical and optical properties of aerosols over an urban location in Spain: seasonal and diurnal variability. Atmos. Chem. Phys. 10, 239-254.

Lyamani, H., Olmo, F.J., Foyo, I., Alados-Arboledas, L., 2011. Black carbon aerosols over an urban area in south-eastern Spain: changes detected after the 2008 economic crisis. Atmos. Environ. 45, 6423-6432.

Ma, N., Birmili, W., 2015. Estimating the contribution of photochemical particle formation to ultrafine particle number averages in an urban atmosphere. Sci. Tot. Environ. 512-513, 154-166.

Manninen, H. E., Nieminen, T., Asmi, E., Gagné, S., Häkkinen, S., Lehtipalo, K., Aalto, P., Kivekäs, N, Vana, M., Mirme, A., Mirme, S., Hörrak, U., Plass-Dülmer, C., Stange, G., Kiss, G., Hoffer, A., Moerman, 
M., Henzing, B., Brinkenberg, M., Kouvarakis, G. N., Bougiatioti, K., O’Dowd, C., Ceburnis, D., Arneth, A., Svenningsson, B., Swietlicki, E., Tarozzi, L., Decesari, S., Sonntag, A., Birmili, W., Wiedensohler, A., Boulon, J., Sellegri, K., Laj, P., Baltensperger, U., Laaksonen, A., Joutsensaari, J., Petäjä, T., Kerminen, V.-M., Kulmala, M., 2010. EUCAARI ion spectrometer measurements at 12 European sites - analysis of new particle formation events. Atmos. Chem. Phys., 10, 7907- 7927, doi:10.5194/acp-10-7907-2010.

Mbengue, S., Alleman, L., Flament, P., 2014. Size-distributed metallic elements in submicroninc and ultrafine atmospheric particles from urban and industrial areas in northern France. Atmospheric Research 135-136, 35-47, https://doi.org/10.1016/j.atmosres.2013.08.010.

Morawska, L., Thomas, S., Jamriska, M., Johnson, G., 1999. The modality of particle size distributions of environmental aerosols. Atmos. Environ. 33, 4401-4411.

Moreira, G. de A, Guerrero-Rascado, J. L., Cazorla, A., Bravo-Aranda, J.A., Landulfo, E., AladosArboledas, L., 2018a. Statistical study of the Planetary Boundary Layer in an urban environment using a combination of microwave radiometer and ceilometer, submitted to International Journal of Climatology.

Moreira, G. de A, Guerrero-Rascado, J., Bravo-Aranda, J.A., Benavent-Oltra, J.A., Ortiz-Amezcua, P., Román, R., Bedoya-Velásquez, A. E., Landulfo, E., Alados-Arboledas, L, 2018b. Study of the planetary boundary layer by microwave radiometer, elastic lidar and Doppler lidar estimation in Southern Iberian Peninsula, submitted to Atmospheric Research.

Müller, T., Henzing, J. S., de Leeuw, G., Wiedensohler, A., Alastuey, A., Angelov, H., Bizjak, M., Collaud Coen, M., Engström, J. E., Gruening, C., Hillamo, R., Hoffer, A., Imre, K., Ivanow, P., Jennings, G., Sun, J. Y., Kalivitis, N., Karlsson, H., Komppula, M., Laj, P., Li, S.-M., Lunder, C., Marinoni, A., Martins dos Santos, S., Moerman, M., Nowak, A., Ogren, J. A., Petzold, A., Pichon, J. M., Rodriquez, S., Sharma, S., Sheridan, P. J., Teinilä, K., Tuch, T., Viana, M., Virkkula, A., Weingartner, E., Wilhelm, R., and Wang, Y. Q., 2011. Characterization and intercomparison of aerosol absorption photometers: result of two intercomparison workshops. Atmos. Meas. Tech., 4, 245-268, https://doi.org/10.5194/amt-4-245-2011.

Navas-Guzmán, F., Fernández-Gálvez, J., Granados-Muñoz, M. J., Guerrero-Rascado, J. L., Bravo-Aranda, J. A., Alados-Arboledas, L. 2014. Tropospheric water vapour and relative humidity profiles from lidar and microwave radiometry, Atmos. Meas. Tech., 7, 1201-1211, https://doi.org/10.5194/amt-7-1201-2014.

Oberdörster, G., Oberdörster, E., Oberdörster, J., 2005. Nanotoxicology: an emerging discipline evolving from studies of ultrafine particles. Environmental Health Perspectives 113, 823-839. 
Park, S., Yu, G., Lee, S., 2018. Optical absorption characteristics of brown carbon aerosols during the KORUS-AQ campaign at an urban site. Atmospheric Research 203, 16-27, https://doi.org/10.1016/j.atmosres.2017.12.002

Patrón, D., Lyamani, H., Titos, G., Casquero-Vera, J.A., Cardell, C., Močnik, G., Alados-Arboledas, L., Olmo, F.J., 2017 Monumental heritage exposure to urban black carbon pollution. Atmos. Environ., 170, $22-32$.

Piedehierro, A. A., Antón, M., Cazorla, A., Alados-Arboledas, L., Olmo, F. J., 2014. Evaluation of enhancement events of total solar irradiance during cloudy conditions at Granada (Southeastern Spain). Atmos. Res. 135, 1-7.

Pérez-Ramírez, D., Lyamani, H., Olmo, F.J., Alados-Arboledas, L. 2013. Retrieval of aerosol microphysical properties by means of sun and star photometry at Granada, Spain. International Journal of Remote Sensing, 34, 9-10.

Pope, C.A., Ezzati, M., Dockery, D.W., 2009. Fine-particulate air pollution and life expectancy in the United States. N. Engl. J. Med. 360, 376-386.

Pope, C.A., Dockery, D.W., 2006. Health effects of fine particulate air pollution: lines that connect. J. Air Waste Manage Assoc. 56, 709-42.

Puustinen, A., $\quad$ Hämeri, K., $\quad$ Pekkanen, $\quad$ J., Kulmala, M., de $\quad$ Hartog, J., Meliefste, K., $\quad$ ten Brink, H.,Kos, G., Katsouyanni, K., Karakatsani, A., Kotronarou, A., Kavouras, I., Meddings, C., Thomas, S., Harrison, R., Ayresi, J., van der Zee, S., Hoek, G., 2007. Spatial variation of particle number and mass over four European cities. Atmos. Environ. 41, 6622-6636.

Querol, X., Alastuey, A., Rodríguez, S., Plana, F., Ruiz, C.R., Cots, N., Massagué, G., Puig, O., 2001. PM10 and PM2.5 source apportionment in the Barcelona Metropolitan Area, Catalonia, Spain. Atmospheric Environment 35/36, 6047-6419.

Querol, X., Alastuey, A., Pey, J., Cusack, M., Pérez, N., Mihalopoulos, N., Theodosi, C., Gerasopoulos, E., Kubilay, N., Moçak, M., 2009. Variability in regional background aerosols within the Mediterranean. Atmos. Chem. Phys. 9, 4575-4591. 
Rahman, M. M., Mazaheri, M., Clifford, S., Morawska, L., 2017. Estimate of main local sources to ambient ultrafine particle number concentration in an urban area. Atmospheric Research 194, 178-189, https://doi.org/10.1016/j.atmosres.2017.04.036.

Rodríguez S., Cuevas E., 2007. The contributions of "minimum primary emissions" and "new particle formation enhancements" to the particle number concentration in urban air. J. Aerosol Sci. 38, 1207-1219.

Rodriguez, S., Van Dingenen, R., Putaud, J.P., Dell'Acqua, A., Pey, J., Querol, X., Alastuey, A., Chenery, S., Ho, K.F., Harrison, R.M., Tardivo, R., Scarnato, B., Gemelli, V., 2007. A study on the relationship between mass concentrations, chemistry and number size distribution of urban fine aerosols in Milan, Barcelona and London. Atmos. Chem. Phys. 7, 2217-2232.

Salma, I., Németh, Z., Kerminen, V.-M., Aalto, P., Nieminen, T., Weidinger, T., Molnár, Á., Imre, K., Kulmala, M., 2016. Regional effect on urban atmospheric nucleation. Atmos. Chem. Phys. 16, 8715-8728, https://doi.org/10.5194/acp-16-8715-2016.

Sandradewi, J., Prévôt, A.S.H., Szidat, S., Perron, N., Alfarra, M.R., Lanz, V.A., Weingartner, E., Baltensperger, U., 2008. Using aerosol light absorption measurements for the quantitative determination of wood burning and traffic emission contributions to particulate matter. Environ. Sci. Technol. 42 (9):33163323. http://dx.doi.org/10.1021/es702253m.

Segura, S., Estellés, V., Titos, G., Lyamani, H., Utrillas, M.P., Zotter, P., et al., 2014. Determination and analysis of in situ spectral aerosol optical properties by a multi instrumental approach. Atmos. Meas. Tech. 7, 2373-2387. http://dx.doi.org/10.5194/amt-7-2373-2014.

Skrabalova, L., Zikova, N., Zdimal, V., 2015. Shrinkage of newly formed particles in an urban environment. Aerosol Air Qual. Res. 15, 1313-1324.

Sorribas, M., Adame, J.A., Olmo, F.J., Vilaplana, J.M., Gil-Ojeda, M., Alados-Arboledas, L., 2015. A longterm study of new particle formation in a coastal environment: Meteorology, gas phase and solar radiation implications. Sci. Total Environ. 511, 723-737.

Sternbeck, J., Sjodin, A., Andreasson, K., 2002. Metal emissions from road traffic and the influence of resuspension - results from two tunnel studies. Atmospheric Environment 36, 4735- 4744.

Stull, R. B., 1988. An Introduction to Boundary Layer Meteorology, vol. 13, Kluwer Academic Publishers, the Netherlands, Dordrecht/Boston/London. 
Titos, G., Foyo-Moreno, I., Lyamani, H., Querol, X., Alastuey, A., Alados-Arboledas, L., 2012. Optical properties and chemical composition of aerosol particles at an urban location: an estimation of the aerosol mass scattering and absorption efficiencies. J. Geophys. Res. 117, D04206. http://dx.doi.org/10.1029/2011JD016671.

Titos, G., Lyamani, H., Pandolfi, M., Alastuey, A., Alados-Arboledas, L., 2014a. Identification of fine (PM1) and coarse (PM10-1) sources of particulate matter in an urban environment. Atmos. Environ. 89, 593-602.

Titos, G., Lyamani, H., Cazorla, A., Sorribas, M., Foyo-Moreno, I., Wiedensohler, A., Alados-Arboledas, L., 2014b. Study of the relative humidity dependence of aerosol light-scattering in southern Spain, Tellus B: Chemical and Physical Meteorology, 66:1, 24536, doi: 10.3402/tellusb.v66.24536

Titos, G., Lyamani, H., Drinovec, L., Olmo, F.J., Močnik, G., Alados-Arboledas, L., 2015. Evaluation of the impact of transportation changes on air quality, Atmos. Environ., 114, 19-31.

Titos, G., del Águila, A., Cazorla, A., Lyamani, H., Casquero-Vera, J.A., Colombi, C., Cuccia, E., Gianelle, V., Močnik, G., Alastuey, A., Olmo, F.J., Alados-Arboledas, L., 2017. Spatial and temporal variability of carbonaceous aerosols: Assessing the impact of biomass burning in the urban environment. Sci. Total Environ. 578, 613-625. https://doi.org/10.1016/j.scitotenv.2016.11.007

Valenzuela A., Olmo, F.J., Lyamani, H., Antón, M., Titos, G., Cazorla, A., Alados-Arboledas, L., 2015. Aerosol scattering and absorption Ångström exponents as indicators of dust and dust-free days over Granada (Spain), Atmos. Res., 154, 1-13.

Wahlin, P., Berkowicz, R., and Palmgren, F., 2006. Characterisation of Traffic- Generated Particulate Matter in Copenhagen. Atmos. Environ. 40, 2151-2159.

Wiedensohler, A., Birmili, W., Nowak, A., Sonntag, A., Weinhold, K., Merkel, M., Wehner, B., Tuch, T., Pfeifer, S., Fiebig, M., Fjäraa, A. M., Asmi, E., Sellegri, K., Depuy, R., Venzac, H., Villani, P., Laj, P., Aalto, P., Ogren, J. A., Swietlicki, E., Williams, P., Roldin, P., Quincey, P., Hüglin, C., FierzSchmidhauser, R., Gysel, M., Weingartner, E., Riccobono, F., Santos, S., Grüning, C., Faloon, K., Beddows, D., Harrison, R., Monahan, C., Jennings, S. G., O’Dowd, C. D., Marinoni, A., Horn, H.-G., Keck, L., Jiang, J., Scheckman, J., McMurry, P. H., Deng, Z., Zhao, C. S., Moerman, M., Henzing, B., de Leeuw, G., Löschau, G., Bastian, S., 2012. Mobility particle size spectrometers: harmonization of technical standards and data 
structure to facilitate high quality long-term observations of atmospheric particle number size distributions. Atmos. Meas. Tech. 5, 657-685, doi:10.5194/amt-5-657-2012.

Yao, X. H., Chio, M. Y., Lau, N. T., Lau, A. P. S., Chan, C. K., Fang, M., 2010. Growth and shrinkage of new particles in the atmosphere in Hong Kong. Aerosol Sci. Tech. 44, 639-650.

Zanatta, M., Gysel, M., Bukowiecki, M., Müller, T., Weingartner, E., Areskoug, H., Fiebig, M., Yttri, K.E., Mihalopoulos, N., Kouvarakis, G., Beddows, D., Harrison, R.M., Cavalli, F., Putaud, J.P., Spindler, G., Wiedensohler, A., Alastuey, A., Pandolfi, M., Sellegri, K., Swietlicki, E., Jaffrezo, J.L., Baltensperger, U., Laj, P., 2016. A European aerosol phenomenology-5: Climatology of black carbon optical properties at 9 regional background sites across Europe. Atmospheric Environment 145, 346-364. 


\section{Table captions}

\section{Table 1:}

Average measured UFP and $\mathrm{N}_{\text {TOT }}$ concentrations (in $\mathrm{cm}^{-3}$ ) and diameter ranges (in $\mathrm{nm}$ ) in different European cities. Period, diameter ranges and references are reported.

\section{Table 2:}

Correlation coefficients between size resolved numerical concentration and $\mathrm{PM}_{1}$ chemical compounds (left) and air quality variables (right). Significant positive and negative correlations at the 0.05 confidence level are marked in red and blue, respectively, in both panels.

\section{Table 3:}

Properties of the individual NPF events during the three campaigns. The total number of days for each campaign is indicated in parenthesis next to the campaign. Also, the mean \pm standard deviation values for each campaign are indicated. The computed NPF properties are as follows: start and end time ( $t_{\text {start }}$ and $t_{\text {end }}$, respectively), duration $(\Delta t)$, formation rate $\left(J_{16}\right)$, growth rate (GR 16.5-30), condensation sinks before and during the growth $\left(\mathrm{CS}_{\mathrm{b}}\right.$ and $\mathrm{CS}_{\mathrm{g}}$, respectively), the maximum concentration in the nucleation size fraction $\left(\mathrm{N}_{\max }\right)$ and the maximum geometric diameter reached during the growth $\left(\mathrm{D}_{\mathrm{g}, \mathrm{max}}\right)$ for each campaign. 


\section{Figure captions}

Fig. 1. (a) Box plots of $N_{N U C}, N_{A I T}, N_{A C C}, N_{T O T}, \sigma_{\text {sp }}(550 \mathrm{~nm}), \sigma_{\mathrm{ap}}(637 \mathrm{~nm}), \operatorname{SAE}(450-700 \mathrm{~nm})$ and AAE (370-950 nm) for the three campaigns. The points inside the box represent mean values; horizontal centre lines within the boxes represent medians; box limits indicate the 25th and 75th percentiles; and the whiskers indicate the 5th and 95th percentiles. (b) $\mathrm{PM}_{1}$ chemical composition of the reconstructed mass during SC-1, SC-2 and $\mathrm{AC}$ in \%.

Fig. 2. Case study in SC-2: 6-9 May 2013: (a) colour map of particle number concentration and geometric modal diameters indicated by points (first mode in black and second mode in grey), (b) temperature and relative humidity, (c) wind speed and direction, (d) experimental and empirical global solar radiation with their respective uncertainties. The colour map and geometrical diameters are plotted with 10-min temporal resolution, the meteorological parameters are hourly means, and the global solar radiation is plotted with 1-min resolution.

Fig. 3. Diurnal evolution of particle number concentration in different size fractions and PBLH during SC-1 (first column), SC-2 (second column), AC-1 (third column) and AC-2 (fourth column). The colour of the bars shows the particle concentration contribution: black indicates urban background (UB); red indicates traffic; blue indicates new particle formation (NPF); and green indicates biomass burning (BB). Solid grey lines indicate the $50^{\text {th }}$ percentile; dashed black lines indicate the $95^{\text {th }}$ percentile (upper line); dashed white lines indicate the $5^{\text {th }}$ percentile (lower line).

Fig. 4. Scatter plots of the chemical paradigm within (a) the nucleation mode $\left(\mathrm{N}_{\mathrm{NUC}, \mathrm{Tr}}\right)$ for $\mathrm{CM}_{\mathrm{ff}}$ during $\mathrm{AC}$ and (b) the accumulation mode $\left(\mathrm{N}_{\mathrm{ACC}, \mathrm{BB}}\right)$ for $\mathrm{CM}_{\mathrm{bb}}$ during $\mathrm{AC}-2$. Shaded areas indicate the experimental SSA $(530 \mathrm{~nm})$ interval values. The size of the dots indicates the particle number concentration. 


\section{TABLES}

Table 1

\begin{tabular}{|c|c|c|c|c|}
\hline City & Period & $\begin{array}{c}\text { UFP } \\
\text { (Diameter range) }\end{array}$ & $\begin{array}{c}\mathrm{N}_{\mathrm{TOT}} \\
\text { (Diameter range) }\end{array}$ & Reference \\
\hline Helsinki, Finland & Oct 2002 - Mar 2004 & -- & $\begin{array}{l}12490 \mathrm{~cm}^{-3} \\
(7-3000 \mathrm{~nm})\end{array}$ & Puustinen et al., 2007 \\
\hline Athens, Greece & Oct 2002 - Mar 2004 & -- & $\begin{array}{c}20276 \mathrm{~cm}^{-3} \\
(7-3000 \mathrm{~nm})\end{array}$ & Puustinen et al., 2007 \\
\hline Amsterdam, Netherlands & Oct 2002 - Mar 2004 & -- & $\begin{array}{c}18090 \mathrm{~cm}^{-3} \\
(7-3000 \mathrm{~nm})\end{array}$ & Puustinen et al., 2007 \\
\hline Birmingham, U.K. & Oct 2002 - Mar 2004 & -- & $\begin{array}{c}18787 \mathrm{~cm}^{-3} \\
(7-3000 \mathrm{~nm})\end{array}$ & Puustinen et al., 2007 \\
\hline Milan, Italy & Nov 2003 - Dec 2004 & $\begin{array}{c}20666 \mathrm{~cm}^{-3} \\
(10-100 \mathrm{~nm})\end{array}$ & $\begin{array}{c}25833 \mathrm{~cm}^{-3} \\
(10-800 \mathrm{~nm})\end{array}$ & Rodriguez et al., 2007 \\
\hline Barcelona, Spain & Nov 2003 - Dec 2004 & $\begin{array}{c}14457 \mathrm{~cm}^{-3} \\
(10-100 \mathrm{~nm})\end{array}$ & $\begin{array}{c}16811 \mathrm{~cm}^{-3} \\
(10-800 \mathrm{~nm})\end{array}$ & Rodriguez et al., $2007^{\mathrm{a}}$ \\
\hline & Jul 2012 - Aug 2013 & $\begin{array}{c}7500 \mathrm{~cm}^{-3} \\
(17.5-100 \mathrm{~nm})\end{array}$ & -- & Brines et al., 2015 \\
\hline London, U.K. & Apr 2004 - Apr 2005 & $\begin{array}{c}9355 \mathrm{~cm}^{-3} \\
(10-100 \mathrm{~nm})\end{array}$ & $\begin{array}{c}11409 \mathrm{~cm}^{-3} \\
(10-415 \mathrm{~nm})\end{array}$ & Rodriguez et al., $2007^{\mathrm{a}}$ \\
\hline Budapest, Hungary & Nov 2008 - Nov 2009 & $\begin{array}{c}8400 \mathrm{~cm}^{-3} \\
(10-100 \mathrm{~nm})\end{array}$ & $\begin{array}{c}10600 \mathrm{~cm}^{-3} \\
(10-1000 \mathrm{~nm})\end{array}$ & Borsós et al., 2012 ${ }^{\mathrm{b}}$ \\
\hline Prague, Czech Republic & Nov 2008 - Nov 2009 & $\begin{array}{c}6000 \mathrm{~cm}^{-3} \\
(10-100 \mathrm{~nm})\end{array}$ & $\begin{array}{c}7300 \mathrm{~cm}^{-3} \\
(10-1000 \mathrm{~nm})\end{array}$ & Borsós et al., 2012 \\
\hline Vienna, Austria & Nov 2007 - Oct 2008 & $\begin{array}{c}5900 \mathrm{~cm}^{-3} \\
(10-100 \mathrm{~nm})\end{array}$ & $\begin{array}{c}8000 \mathrm{~cm}^{-3} \\
(10-1000 \mathrm{~nm})\end{array}$ & Borsós et al., 2012 \\
\hline Madrid, Spain & Jan 2007- Dec 2008 & $\begin{array}{c}7000 \mathrm{~cm}^{-3} \\
(17.5-100 \mathrm{~nm})\end{array}$ & -- & Brines et al., 2015 \\
\hline Rome, Italy & Sep 2007-May 2009 & $\begin{array}{c}5000 \mathrm{~cm}^{-3} \\
(17.5-100 \mathrm{~nm})\end{array}$ & -- & Brines et al., 2015 \\
\hline \multirow[t]{3}{*}{ Granada, Spain } & Apr 2012-May 2012 & $\begin{array}{c}6800 \mathrm{~cm}^{-3} \\
(16.5-100 \mathrm{~nm})\end{array}$ & $\begin{array}{c}7600 \mathrm{~cm}^{-3} \\
(16.5-697.8 \mathrm{~nm})\end{array}$ & Present study \\
\hline & Apr 2013-May 2013 & $\begin{array}{c}5800 \mathrm{~cm}^{-3} \\
(16.5-100 \mathrm{~nm})\end{array}$ & $\begin{array}{c}6900 \mathrm{~cm}^{-3} \\
(16.5-697.8 \mathrm{~nm})\end{array}$ & Present study \\
\hline & Oct 2013-Nov 2013 & $\begin{array}{c}9900 \mathrm{~cm}^{-3} \\
(16.5-100 \mathrm{~nm})\end{array}$ & $\begin{array}{c}11900 \mathrm{~cm}^{-3} \\
(16.5-697.8 \mathrm{~nm})\end{array}$ & Present study \\
\hline
\end{tabular}

\footnotetext{
${ }^{a}$ Computed from data in the article.
}

b Median values of daily atmospheric concentrations. 
Table 2

\begin{tabular}{c|cccccc|ccccccc}
$\begin{array}{c}\text { Diameter } \\
\text { range }\end{array}$ & Minerals & $\begin{array}{c}\text { Spray } \\
\text { spa }\end{array}$ & $\mathrm{OM}$ & $\mathrm{EC}$ & $\mathrm{SIA}$ & Metals & $\mathrm{CO}$ & $\mathrm{NO}_{2}$ & $\mathrm{NO}$ & $\mathrm{SO}_{2}$ & $\mathrm{O}_{3}$ & $\mathrm{PM}_{10}$ & $\mathrm{BC}$ \\
\hline $16.5-20$ & 0.37 & -0.49 & 0.21 & 0.63 & 0.05 & 0.40 & 0.50 & 0.55 & 0.44 & 0.15 & -0.40 & 0.19 & 0.58 \\
$20-30$ & 0.37 & -0.63 & 0.35 & 0.63 & -0.15 & 0.29 & 0.63 & 0.69 & 0.58 & 0.22 & -0.54 & 0.31 & 0.75 \\
$30-50$ & 0.61 & -0.14 & 0.57 & 0.37 & -0.65 & 0.19 & 0.70 & 0.79 & 0.70 & 0.37 & -0.64 & 0.44 & 0.85 \\
$50-100$ & 0.26 & -0.14 & 0.85 & 0.94 & 0.26 & 0.53 & 0.71 & 0.78 & 0.69 & 0.55 & -0.58 & 0.64 & 0.84 \\
$100-200$ & -0.25 & -0.62 & 0.69 & 0.82 & 0.68 & 0.26 & 0.62 & 0.63 & 0.55 & 0.53 & -0.39 & 0.77 & 0.72 \\
$200-300$ & -0.25 & -0.36 & 0.63 & 0.76 & 0.73 & 0.22 & 0.58 & 0.55 & 0.48 & 0.47 & -0.35 & 0.80 & 0.67 \\
$300-400$ & 0.03 & -0.24 & 0.71 & 0.82 & 0.52 & 0.37 & 0.59 & 0.57 & 0.52 & 0.51 & -0.44 & 0.81 & 0.71 \\
$400-697.8$ & 0.25 & -0.18 & 0.79 & 0.85 & 0.28 & 0.36 & 0.65 & 0.64 & 0.60 & 0.49 & -0.52 & 0.73 & 0.81 \\
\hline
\end{tabular}


Table 3

\begin{tabular}{|c|c|c|c|c|c|c|c|c|c|c|}
\hline Campaign & Day & $\begin{array}{c}\mathrm{t}_{\text {start }} \\
\text { (hh:mm) }\end{array}$ & $\begin{array}{c}\mathrm{t}_{\text {end }} \\
(\mathrm{hh}: \mathrm{mm})\end{array}$ & $\begin{array}{c}\Delta \mathrm{t} \\
(\mathrm{hh}: \mathrm{mm})\end{array}$ & $\begin{array}{c}\mathrm{J}_{16} \\
\left(\mathrm{~cm}^{-3} \mathrm{~s}^{-1}\right)\end{array}$ & $\begin{array}{l}\mathrm{GR}_{16.5-30} \\
\left(\mathrm{~nm} \mathrm{~h}^{-1}\right)\end{array}$ & $\begin{array}{l}\mathrm{CS}_{\mathrm{b}} \\
\left(\mathrm{s}^{-1}\right)\end{array}$ & $\begin{array}{l}\mathrm{CS}_{\mathrm{g}} \\
\left(\mathrm{s}^{-1}\right)\end{array}$ & $\begin{array}{c}\mathrm{N}_{\max } \\
\left(\mathrm{cm}^{-3}\right)\end{array}$ & $\begin{array}{l}\mathrm{D}_{\mathrm{g} \max } \\
(\mathrm{nm})\end{array}$ \\
\hline & $18 / 04 / 12$ & $11: 55$ & $14: 40$ & 2.7 & 1.5 & 3.1 & 0.0055 & 0.0044 & 8500 & 24 \\
\hline \multirow{2}{*}{$\begin{array}{c}\text { SC-1 } \\
\text { (14 days) }\end{array}$} & $23 / 04 / 12$ & $14: 45$ & $22: 20$ & 7.6 & 2.0 & 2.9 & 0.0054 & 0.0060 & 5300 & 40 \\
\hline & $25 / 04 / 12$ & $14: 15$ & $19: 40$ & 5.5 & 1.6 & 4.7 & 0.0085 & 0.0062 & 6800 & 41 \\
\hline $\begin{array}{c}\text { Mean } \pm \\
\text { SD }\end{array}$ & & $\begin{array}{c}13: 40 \pm \\
01: 30\end{array}$ & $\begin{array}{c}18: 50 \pm 0 \\
4: 00\end{array}$ & $5.3 \pm 2.4$ & $1.7 \pm 0.3$ & $3.6 \pm 1.0$ & $\begin{array}{c}0.0065 \pm \\
0.0018\end{array}$ & $\begin{array}{c}0.0055 \pm \\
0.0010\end{array}$ & $\begin{array}{c}6900 \pm \\
1600\end{array}$ & $35 \pm 9$ \\
\hline \multirow{6}{*}{$\begin{array}{c}\mathrm{SC}-2 \\
\text { (17 days) }\end{array}$} & $23 / 04 / 13$ & $14: 30$ & $16: 20$ & 2 & 0.9 & 7.4 & 0.0079 & 0.0065 & 4200 & 30 \\
\hline & $26 / 04 / 13$ & $11: 10$ & $1: 30$ & 14 & 1.1 & 2.5 & 0.0065 & 0.0078 & 8100 & 53 \\
\hline & $01 / 05 / 13$ & $11: 30$ & $0: 10$ & 14 & 1.6 & 3.7 & 0.0055 & 0.0057 & 4600 & 55 \\
\hline & $07 / 05 / 13$ & $13: 50$ & $3: 40$ & 14 & 0.9 & 2.4 & 0.0111 & 0.0067 & 3700 & 35 \\
\hline & $08 / 05 / 13$ & $12: 30$ & $3: 30$ & 15 & 1.0 & 3.6 & 0.0112 & 0.0066 & 9100 & 58 \\
\hline & $09 / 05 / 13$ & 11:00 & $15: 20$ & 4 & 1.8 & 4.4 & 0.0100 & 0.0045 & 9000 & 23 \\
\hline $\begin{array}{c}\text { Mean } \pm \\
\text { SD }\end{array}$ & & $\begin{array}{c}12: 25 \pm \\
01: 30\end{array}$ & $\begin{array}{c}22: 45 \pm \\
05: 30\end{array}$ & $11 \pm 6$ & $1.2 \pm 0.4$ & $4.0 \pm 1.9$ & $\begin{array}{c}0.0087 \pm \\
0.0024\end{array}$ & $\begin{array}{c}0.0063 \pm \\
0.0011\end{array}$ & $\begin{array}{c}6500 \pm \\
2500\end{array}$ & $43 \pm 15$ \\
\hline \multirow{2}{*}{$\begin{array}{c}\text { AC } \\
\text { (29 days) }\end{array}$} & $17 / 10 / 13$ & $13: 10$ & $2: 40$ & 13.5 & 1.18 & 3.0 & 0.021 & 0.012 & 6200 & 57 \\
\hline & $11 / 11 / 13$ & $16: 10$ & $5: 00$ & 12.8 & 1.04 & 1.8 & 0.009 & 0.004 & 8500 & 36 \\
\hline $\begin{array}{c}\text { Mean } \pm \\
\text { SD }\end{array}$ & & $\begin{array}{c}14: 40 \pm \\
02: 10\end{array}$ & $\begin{array}{c}03: 50 \pm \\
01: 40\end{array}$ & $\begin{array}{c}13.2 \pm \\
0.5\end{array}$ & $\begin{array}{c}1.11 \pm \\
0.10\end{array}$ & $2.4 \pm 0.9$ & $\begin{array}{c}0.015 \pm \\
0.008\end{array}$ & $\begin{array}{c}0.008 \pm \\
0.006\end{array}$ & $\begin{array}{c}7400 \pm \\
1600\end{array}$ & $47 \pm 15$ \\
\hline
\end{tabular}




\section{FIGURES}

(a)
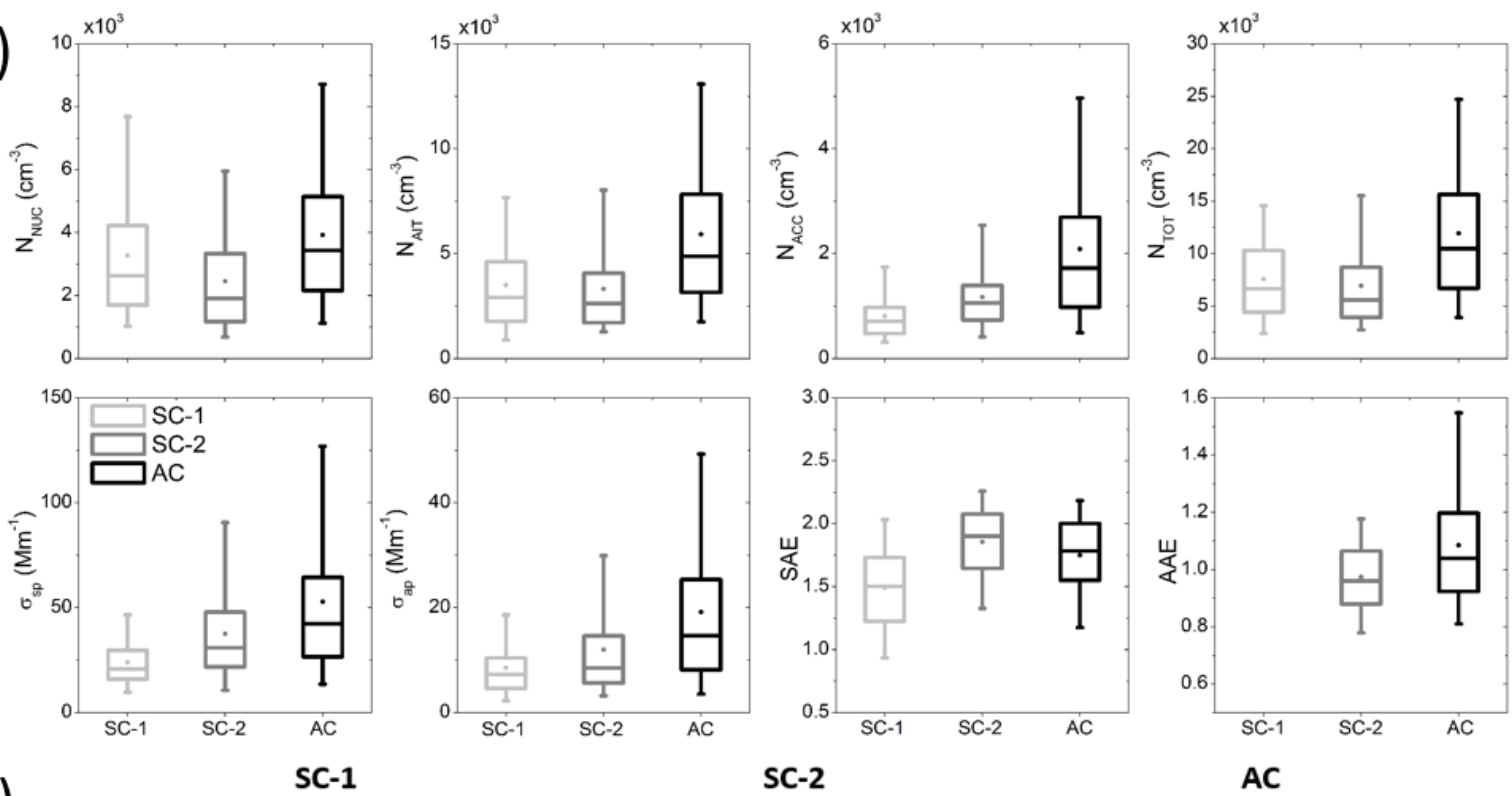

(b)

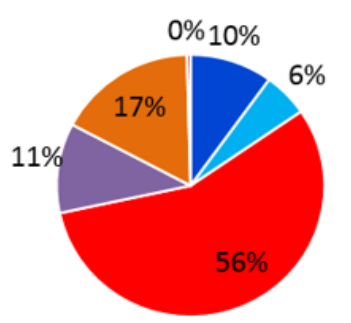

SC-2

AC

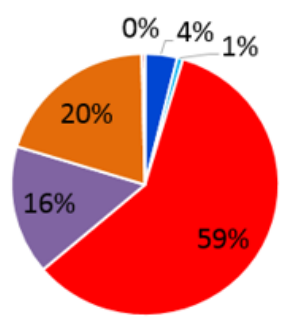

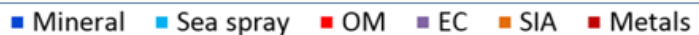

Figure 1 


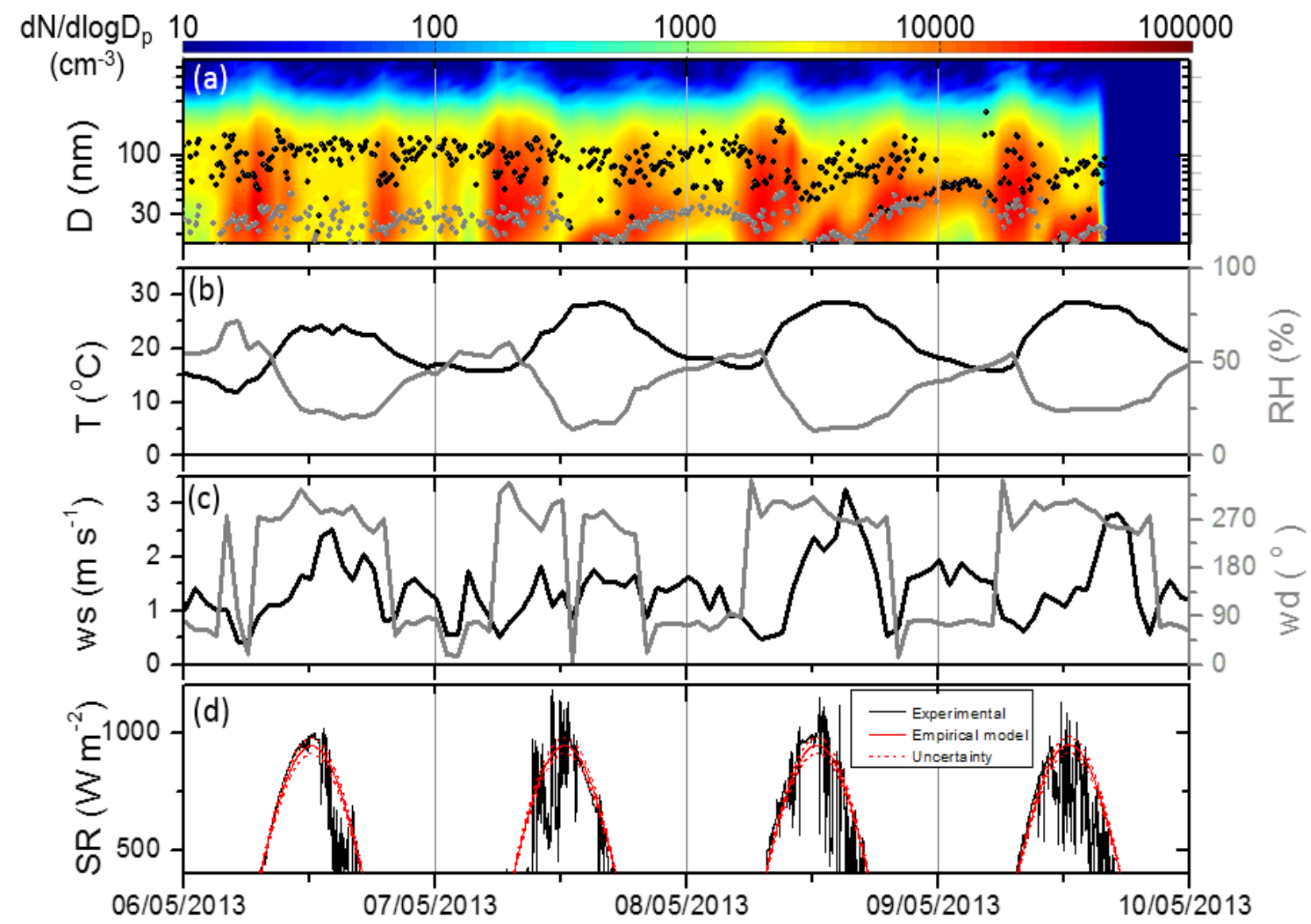

Figure 2 


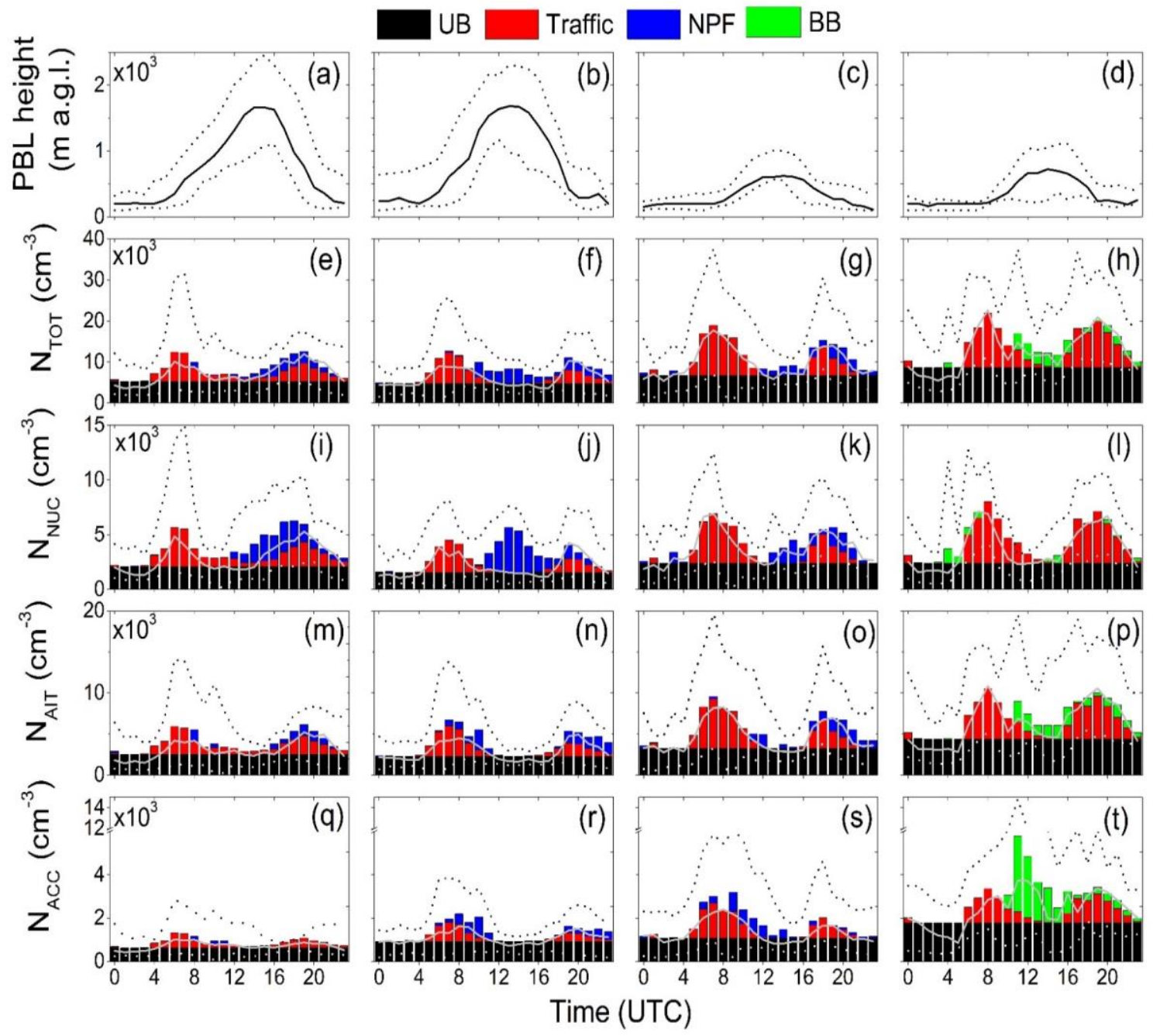

Figure 3 


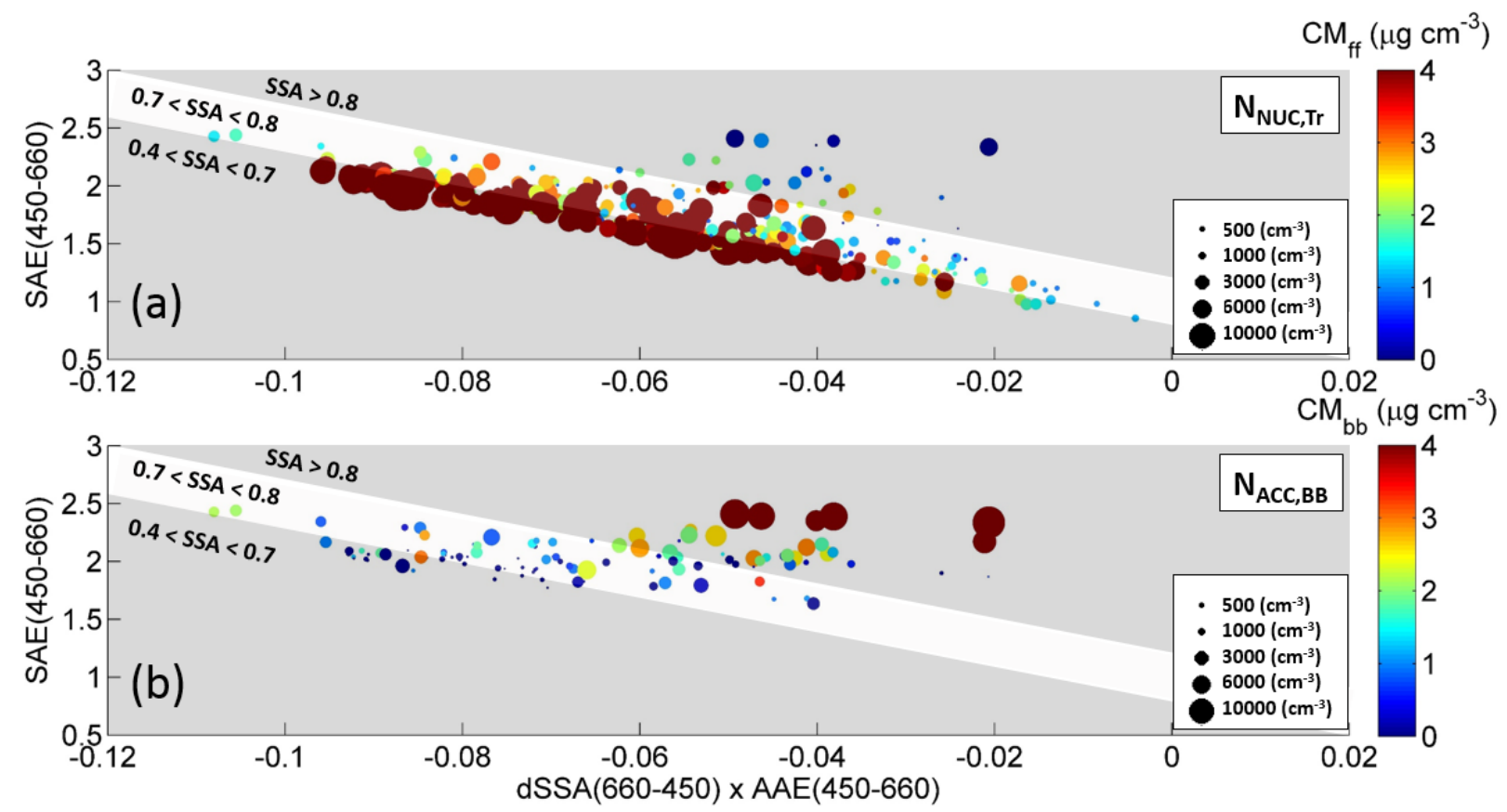

Figure 4 


\section{SUPPLEMENTARY MATERIAL}

Table S1: Mean, standard deviation (SD), median and percentiles 5th and 95th of particle number concentrations, $\sigma_{\mathrm{sp}}$ at $550 \mathrm{~nm}, \sigma_{\mathrm{ap}}$ at 637 (SC-1) and $660 \mathrm{~nm}$ (SC-2 and AC), SAE in the pair 450-700 nm and AAE in the pair 470-660 nm.

\begin{tabular}{|c|c|c|c|c|c|c|c|c|c|c|c|c|c|c|c|}
\hline & \multicolumn{5}{|c|}{ SC-1 } & \multicolumn{5}{|c|}{ SC-2 } & \multicolumn{5}{|c|}{$\mathrm{AC}$} \\
\hline Variable (units) & Mean & SD & Median & P5 & P95 & Mean & SD & Median & P5 & P95 & Mean & SD & Median & P5 & P95 \\
\hline $\mathrm{N}_{\mathrm{NUC}}\left(\mathrm{cm}^{-3}\right)$ & 3280 & 2230 & 2630 & 1020 & 7760 & 2460 & 1720 & 1930 & 680 & 6100 & 3930 & 2350 & 3430 & 1080 & 10120 \\
\hline $\mathrm{N}_{\text {AIT }}\left(\mathrm{cm}^{-3}\right)$ & 3500 & 2300 & 2920 & 880 & 7680 & 3310 & 2260 & 2610 & 1270 & 8040 & 5920 & 3640 & 4880 & 2170 & 15790 \\
\hline $\mathrm{N}_{\mathrm{ACC}}\left(\mathrm{cm}^{-3}\right)$ & 800 & 450 & 710 & 310 & 1750 & 1170 & 670 & 1060 & 410 & 2550 & 2090 & 1120 & 1730 & 370 & 7570 \\
\hline $\mathrm{N}_{\text {Tот }}\left(\mathrm{cm}^{-3}\right)$ & 7580 & 4450 & 6670 & 2370 & 14550 & 6930 & 4250 & 5580 & 2710 & 15730 & 11940 & 6800 & 10480 & 4420 & 30600 \\
\hline$\sigma_{\mathrm{sp}}\left(\mathrm{Mm}^{-1}\right)$ & 24 & 12 & 21 & 10 & 47 & 37 & 23 & 31 & 11 & 91 & 53 & 43 & 43 & 10 & 73 \\
\hline$\sigma_{\mathrm{ap}}\left(\mathrm{Mm}^{-1}\right)$ & 9 & 6 & 7 & 2 & 19 & 11 & 10 & 8 & 2 & 24 & 20 & 17 & 16 & 3 & 54 \\
\hline SAE & 1.5 & 0.3 & 1.5 & 0.9 & 2.0 & 1.9 & 0.3 & 1.9 & 1.3 & 2.3 & 1.8 & 0.3 & 1.8 & 1.8 & 2.2 \\
\hline AAE & -- & -- & -- & -- & -- & 0.82 & 0.12 & 0.81 & 0.63 & 1.0 & 0.90 & 0.20 & 0.86 & 0.68 & 1.44 \\
\hline
\end{tabular}


Table S2: Correlation coefficients of the individual compounds showing significant correlations at 0.05 confidence level. The values marked in blue show significant negative correlations while values in red show significant positive correlations. Also, the group of compounds is marked on the top.

\begin{tabular}{|c|c|c|c|c|c|c|c|c|c|}
\hline \multirow{2}{*}{$\begin{array}{c}\text { Diameter } \\
\text { range }\end{array}$} & \multicolumn{4}{|c|}{ Mineral } & \multicolumn{3}{|c|}{ Sea spray } & \multicolumn{2}{|c|}{ SIA } \\
\hline & $\mathbf{C a}$ & $\mathbf{F e}$ & $\mathbf{K}$ & $\mathrm{CO}_{3}=$ & $\mathrm{Na}$ & $\mathrm{mSO}_{4}{ }^{2-}$ & Cl & $\mathrm{nmSO}_{4}{ }^{2-}$ & $\mathrm{NO}_{3}$ \\
\hline $16.5-20$ & -0.23 & 0.68 & 0.46 & 0.08 & 0.06 & 0.04 & -0.50 & 0.02 & 0.22 \\
\hline $20-30$ & -0.08 & 0.59 & 0.52 & 0.22 & 0.31 & 0.19 & -0.66 & -0.16 & 0.05 \\
\hline $30-50$ & 0.52 & 0.31 & 0.58 & 0.70 & 0.90 & 0.82 & -0.25 & -0.69 & -0.26 \\
\hline $50-100$ & -0.59 & 0.39 & 0.69 & -0.04 & 0.38 & 0.45 & -0.21 & 0.04 & 0.70 \\
\hline $100-200$ & -0.65 & 0.13 & 0.34 & -0.51 & -0.06 & -0.05 & -0.55 & 0.50 & 0.84 \\
\hline $200-300$ & -0.64 & 0.12 & 0.25 & -0.51 & -0.17 & -0.07 & -0.28 & 0.55 & 0.90 \\
\hline $300-400$ & -0.49 & 0.27 & 0.47 & -0.29 & 0.06 & 0.09 & -0.15 & 0.34 & 0.90 \\
\hline \multirow[t]{3}{*}{$400-697.8$} & -0.35 & 0.35 & 0.57 & -0.02 & 0.29 & 0.34 & -0.22 & 0.09 & 0.80 \\
\hline & \multicolumn{9}{|c|}{ Metals } \\
\hline & $\mathbf{V}$ & $\mathrm{Cr}$ & Mn & $\mathrm{Cu}$ & $\mathrm{Zn}$ & As & $\mathbf{R b}$ & $\mathrm{Sr}$ & $\mathbf{Y}$ \\
\hline $16.5-20$ & 0.64 & -0.86 & 0.66 & 0.47 & 0.34 & 0.45 & 0.38 & 0.82 & -0.39 \\
\hline $20-30$ & 0.42 & -0.87 & 0.60 & 0.63 & 0.46 & 0.22 & 0.45 & 0.50 & -0.35 \\
\hline $30-50$ & -0.02 & 0.07 & 0.32 & 0.79 & 0.80 & -0.43 & 0.63 & 0.32 & -0.39 \\
\hline $50-100$ & 0.38 & -0.38 & 0.36 & 0.55 & 0.64 & 0.52 & 0.65 & 0.24 & -0.51 \\
\hline $100-200$ & 0.21 & -0.54 & 0.06 & 0.21 & 0.18 & 0.76 & 0.26 & -0.04 & -0.31 \\
\hline $200-300$ & 0.25 & -0.52 & 0.07 & 0.17 & 0.13 & 0.77 & 0.20 & 0.06 & -0.41 \\
\hline $300-400$ & 0.36 & -0.47 & 0.35 & 0.37 & 0.38 & 0.71 & 0.47 & 0.21 & -0.57 \\
\hline \multirow[t]{2}{*}{$400-697.8$} & 0.36 & -0.43 & 0.49 & 0.60 & 0.59 & 0.51 & 0.61 & 0.29 & -0.68 \\
\hline & $\mathbf{Z r}$ & $\mathbf{N b}$ & Sn & Sb & La & $\mathrm{Ce}$ & Hf & $\mathbf{P b}$ & \\
\hline $16.5-20$ & 0.14 & 0.34 & 0.58 & 0.67 & 0.66 & 0.75 & -0.79 & 0.50 & \\
\hline $20-30$ & -0.02 & 0.45 & 0.56 & 0.51 & 0.53 & 0.61 & -0.68 & 0.49 & \\
\hline $30-50$ & -0.03 & 0.50 & 0.50 & -0.08 & 0.19 & 0.05 & -0.55 & 0.08 & \\
\hline $50-100$ & -0.49 & 0.78 & 0.61 & 0.08 & 0.41 & 0.52 & -0.46 & 0.75 & \\
\hline $100-200$ & -0.82 & 0.83 & 0.29 & -0.02 & 0.12 & 0.46 & -0.12 & 0.83 & \\
\hline $200-300$ & -0.79 & 0.80 & 0.30 & 0.01 & 0.09 & 0.40 & -0.17 & 0.78 & \\
\hline $300-400$ & -0.75 & 0.84 & 0.49 & 0.16 & 0.29 & 0.49 & -0.46 & 0.88 & \\
\hline $400-697.8$ & -0.64 & 0.85 & 0.64 & 0.20 & 0.33 & 0.46 & -0.60 & 0.85 & \\
\hline
\end{tabular}




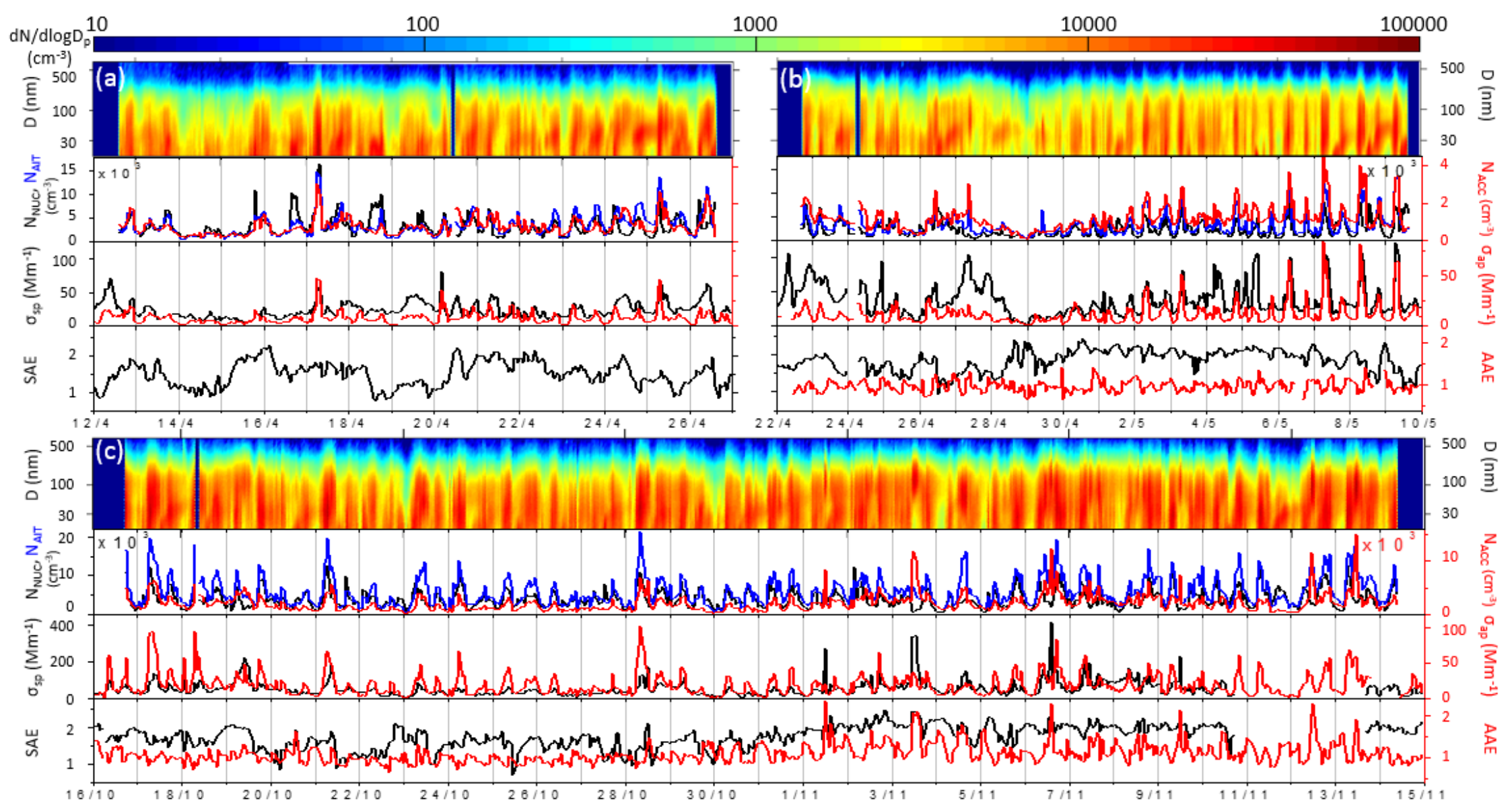

Fig. S1: Time series of $\mathrm{dN} / \mathrm{d} \log \mathrm{D}_{\mathrm{p}}$ (color maps; 10-min values) and hourly averaged $\mathrm{N}_{\mathrm{NUC}}, \mathrm{N}_{\mathrm{AIT}}, \mathrm{N}_{\mathrm{ACC}}, \sigma_{\mathrm{sp}}, \sigma_{\mathrm{ap}}$, SAE and AAE during (a) SC-1 (2012), (b) SC-2 (2013) and (c) AC (2013). The wavelengths used are: $550 \mathrm{~nm}$ for $\sigma_{\mathrm{sp}}$ and $637 \mathrm{~nm}$ for $\sigma_{\mathrm{ap}}$ (using MAAP absorption coefficients); the pair 450-700 $\mathrm{nm}$ for SAE and 370-950 $\mathrm{nm}$ for AAE. Note that Y-axis scales are the same for SC-1 and SC-2 and X-axis is the date in format 'dd/mm'. 
(a)

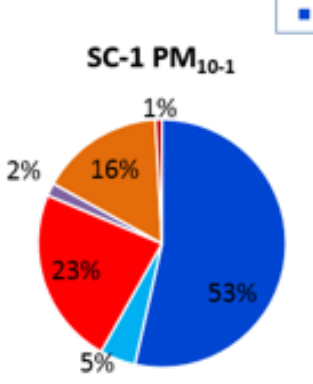

SC-1 PM 1

$0 \% 10 \%$

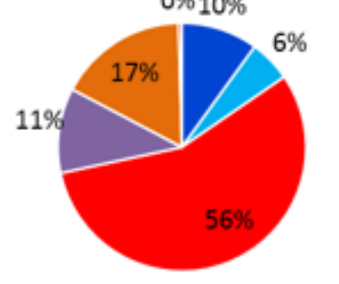

(b)

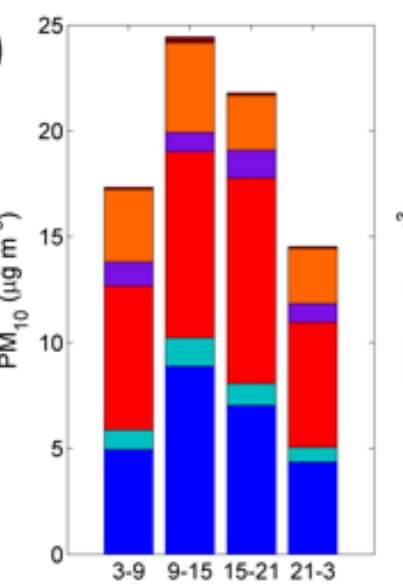

- Mineral = Sea spray "OM $=$ EC $=$ SIA $=$ Metals

SC-2 PM 10 -1

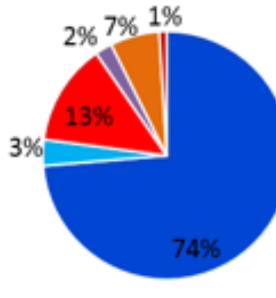

SC-2 PM
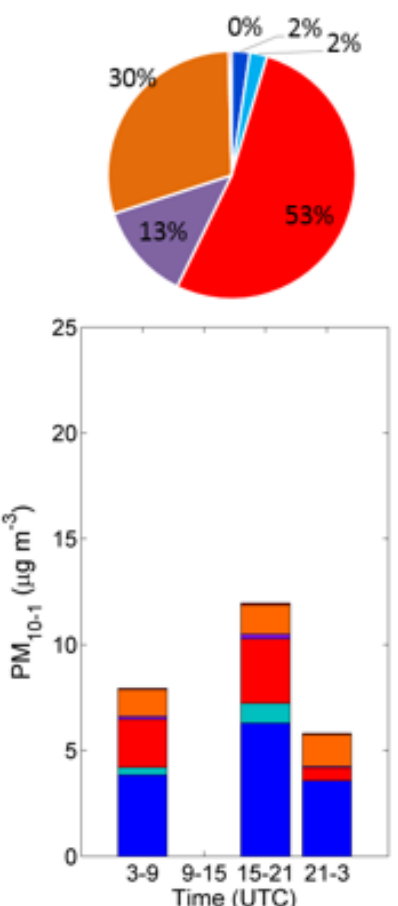

AC PM $10-1$

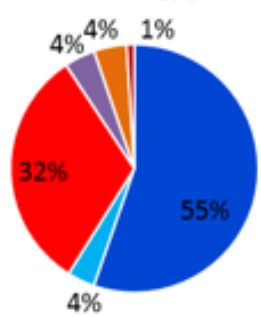

AC $\mathrm{PM}_{1}$

$0 \% \quad 4 \% 1 \%$
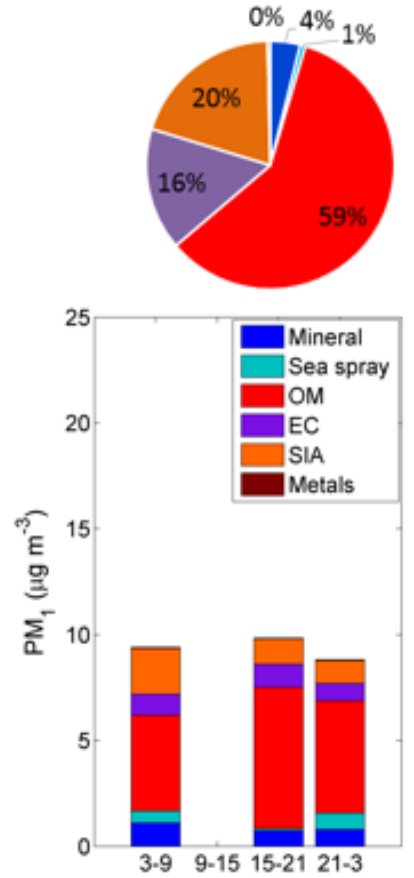

Fig. S2: (a) $\mathrm{PM}_{10-1}$ (upper pie charts) and $\mathrm{PM}_{1}$ (bottom pie charts) chemical composition during SC-1 (left), SC-2 (middle) and AC (right) in \%. (b) Bar chart of one day sampling (24/04/12 - SC-1) for: (left) $\mathrm{PM}_{10}$, (middle) $\mathrm{PM}_{10-1}$, (right) $\mathrm{PM}_{1}$. 